\title{
The Role of Hydrological Initial Conditions on Atmospheric River Floods in the Russian River Basin 0
}

\author{
QIAN CAO AND Ali MEHRAN \\ Department of Geography, University of California, Los Angeles, Los Angeles, California
}

\author{
F. MARTIN RALPH
}

Center for Western Weather and Water Extremes, Scripps Institution of Oceanography at University of California, San Diego, California

DENNIS P. LETTENMAIER

Department of Geography, University of California, Los Angeles, Los Angeles, California

(Manuscript received 7 February 2019, in final form 9 June 2019)

\begin{abstract}
A body of work over the last decade or so has demonstrated that most major floods along the U.S. West Coast are attributable to atmospheric rivers (ARs). Recent studies suggest that observed changes in extreme precipitation associated with a general warming of the western United States have not necessarily led to corresponding changes in floods, and changes in antecedent hydrological conditions could be a primary missing link. Here we examine the role of antecedent soil moisture (ASM) conditions on historical AR flooding on California's Russian River basin, a coastal watershed whose winter precipitation extremes are dominated by ARs. We examined the effect of observed warming on ASM for the period 1950-2017. We first constructed an hourly precipitation product at $1 / 32^{\circ}$ spatial resolution. We used the Distributed Hydrology Soil Vegetation Model (DHSVM) to estimate storm total runoff volumes and soil moisture. We found that up to $95 \%$ of peaks-over-threshold (POT) extreme discharge events were associated with ARs. The storm runoff-precipitation ratio generally increased with wetter prestorm conditions, and the relationship was stronger as drainage area increased. We found no trends in extreme precipitation but weak downward trends in extreme discharge. The latter were mostly consistent with weak downward trends in the first 2-day storm precipitation. We found no trends in ASM; however, ASM was significantly correlated with peak flow. The ASM was affected more by antecedent precipitation than evapotranspiration, and hence temperature increases had weak effects on ASM.
\end{abstract}

\section{Introduction}

A body of work over the last decade or so has demonstrated that most major floods along the U.S. West Coast are attributable to atmospheric rivers (ARs; e.g., Ralph et al. 2006; Dettinger et al. 2011; Neiman et al. 2011; Barth et al. 2017), which are long, narrow, and transient corridors of anomalously strong horizontal

Supplemental information related to this paper is available at the Journals Online website: https://doi.org/10.1175/JHM-D-190030.s1.

Corresponding author: Dennis P. Lettenmaier, dlettenm@ ucla.edu water vapor transport (Zhu and Newell 1998; Ralph et al. 2018). Accompanied by warm air temperatures and strong low-level winds, AR landfalls may lead to enhanced precipitation when interacting with the complex topography (Neiman et al. 2002). ARs make up 30\%$50 \%$ of annual precipitation on the U.S. Pacific coast and thus contribute to the region's water supply and water resources (Guan et al. 2010; Dettinger et al. 2011; Lavers and Villarini 2015; Lamjiri et al. 2017). However, strong AR events can result in heavy precipitation and lead to disastrous flooding such as the coastal flooding in Southern California during late March 2018. Landfalling ARs account for $60 \%-100 \%$ of extreme storms (with precipitation-total return intervals greater than 2 years) along the U.S. West Coast (Lamjiri et al. 2017) and 
$40 \%-75 \%$ of extreme wind and precipitation events (exceeding the 98th percentile) over $40 \%$ of the coastlines worldwide particularly in the midlatitudes (Waliser and Guan 2017). Moreover, ARs contribute more than half of the mean annual runoff and more than $80 \%$ of annual peak flows along the Pacific Northwest and Northern California coast (Paltan et al. 2017; Barth et al. 2017).

Recent years have witnessed the rapid development of AR detection methods based on integrated water vapor (IWV) and IWV transport (IVT; Shields et al. 2018) as well as increased ability to forecast ARs (e.g., Nayak et al. 2014; Lavers et al. 2016; Cordeira et al. 2017; DeFlorio et al. 2018; Martin et al. 2018). A number of studies have been carried out to examine the key factors linking ARs and precipitation, such as the AR duration (Ralph et al. 2013b; Lamjiri et al. 2017; Nayak and Villarini 2018), (IVT) intensity, and direction with respect to regional terrain orientation (Ralph et al. 2003; Neiman et al. 2011, 2013; Hughes et al. 2014; Hecht and Cordeira 2017). The first two factors can be used as a scale to categorize AR events and their potential hydrologic impacts at a given location (Ralph et al. 2019a).

Hydrologic initial conditions play an important role in the natural links between precipitation and floods. Previous studies examined the critical threshold of antecedent soil moisture (ASM) to differentiate high or low runoff ratios (the amount of storm runoff divided by the amount of storm precipitation) based on in situ observations. For example, Penna et al. (2011) assessed the effect of ASM in the upper-30-cm layer (of clay loam/ silty clay loam) on 40 runoff events with precipitation greater than $6 \mathrm{~mm}$ during June 2005-October 2006 in an alpine headwater catchment with a drainage area of $1.9 \mathrm{~km}^{2}$. They found that the runoff ratio was mostly below 0.09 when soil saturation (percentage of porosity) was below $70 \%$. Similarly, Radatz et al. (2013) found that runoff ratios were near zero when soil saturation was below $80 \%$ in the upper-30-cm layer of silt loam during March 2004-September 2007 across 6 small agricultural watersheds in southwestern Wisconsin with areas ranging within $0.06-0.17 \mathrm{~km}^{2}$. Due to limitations of in situ observations, these studies focused on very small catchments.

The development of satellite-based large-scale soil moisture monitoring products using $\mathrm{L}$ band microwave radiometry in recent years, such as the European Space Agency's Soil Moisture and Ocean Salinity (SMOS) mission (Kerr et al. 2010) and the NASA's Soil Moisture Active Passive (SMAP) mission (Entekhabi et al. 2010), have enabled studies at larger scales. Crow et al. (2017) examined the relationship between ASM from the Level-4 SMAP (SMAP_L4) product, which is based on the assimilation of SMAP brightness temperature observations into the Catchment land surface model (LSM), and the storm runoff ratio from precipitation and streamflow observations in the south-central United States. They found that the runoff ratio showed a much stronger (rank) correlation with prestorm surface soil moisture than storm total precipitation.

Sensitivity analyses using model simulations can help to better understand the role of ASM on floods. Castillo et al. (2003) conducted a stochastic sensitivity analysis in three small catchments $\left(0.06-0.24 \mathrm{~km}^{2}\right)$ in semiarid southeast Spain. By examining the simulation results from a combination of soil moisture and storm precipitation scenarios, they showed that the ASM was an important controlling factor of runoff during lowand medium-intensity storms but not for high-intensity storms, during which floods were dominated by the infiltration-excess mechanism. A sensitivity analysis in the Fella basin $\left(623 \mathrm{~km}^{2}\right)$ in Italy showed similar results (Nikolopoulos et al. 2011). Their study used a spatially distributed hydrologic model to examine the sensitivity of flash flood response to initial wetness conditions by adjusting water table depth and thus the initial soil moisture profile. In addition, Nikolopoulos et al. (2011) found that the sensitivity of flood response to initial wetness increased for increasing basin scale by examining the sensitivity across catchments with areas of 24 , 165, and $329 \mathrm{~km}^{2}$. Thomas et al. (2016) examined the sensitivity of simulated peak flows to antecedent soil saturation in a $45 \mathrm{~km}^{2}$ catchment in Iowa. They found that ASM became less important to peak flows as rainfall depth increased.

Given the awareness of the importance of prestorm wetness conditions on runoff, some studies have examined the impact of ASM on AR flooding. Leung and Qian (2009) ran a 20-yr simulation of regional climate with the Weather Research and Forecasting (WRF) Model to examine AR-induced heavy precipitation and flooding events over the western U.S. from 1980 to 2000. They found that for two selected events with similar amounts of total precipitation, different ASM conditions could lead to a difference of more than 0.3 in the runoff ratio. Neiman et al. (2014) closely examined a single AR flood event in Northern California using in situ observations and found that flooding occurred shortly after the soil water content exceeded its field capacity during the heaviest rains at one study site. Ralph et al. (2013b) examined the impact of precursor soil moisture conditions on the streamflow in a subbasin (drainage area $163 \mathrm{~km}^{2}$ ) of the Russian River basin in Northern California during 91 AR events from 2004 to 2010. They used hourly observations of upslope IWV flux from the local AR observatory, precipitation and streamflow from gauges, as well as soil moisture from 
NOAA's Hydrometeorology Testbed (HMT; Ralph et al. 2013a). They found that AR-induced heavy precipitation did not lead to significant streamflow when precursor soil moisture was below 20\% (volumetric water content) and that extreme floods might occur when ASM was greater than about $35 \%$.

Recent studies have examined the role of changes in soil moisture on floods in a warming world. For example, Woldemeskel and Sharma (2016) examined trends in annual maximum precipitation and accompanying antecedent soil moisture [with antecedent precipitation index (API) as a surrogate] over the past century globally. In North America, they found positive trends in annual maximum rainfall but no trend in API, which they argued partially explained the lack of positive trends in annual maximum flows in this region. Berghuijs et al. (2016) argued that soil moisture changes are particularly important in areas, such as California, where flooding is caused by a large single precipitation excess event. By analyzing historical station records of precipitation and streamflow, Wasko and Sharma (2017) found that increased heavy rainfall events caused by warming did not lead to similar increases in the streamflow in most regions globally, suggesting the importance of initial moisture conditions in these areas. They found that the intensity of extreme precipitation (exceeding the 99th percentile) has decreased in the U.S. Northwest (including Northern California) as temperatures have increased; this is in contrast to the general increasing pattern in the subtropics and temperate regions. Similar decreasing trends in both the annual maximum precipitation and the annual frequency of heavy precipitation in these regions were found by Mallakpour and Villarini (2017), based on the Climate Prediction Center (CPC) gridded daily precipitation product during the period 1948-2012. The extreme streamflow in these areas showed even greater negative response than extreme precipitation did to increased temperatures (Wasko and Sharma 2017), indicating the influence of ASM conditions. Yet, it is unclear whether the greater negative response of extreme discharge was caused by increased temperature or antecedent precipitation conditions (Sharma et al. 2018).

Given this background, we address here the following motivating questions:

1) What is the role of ASM on historical AR flooding in California's Russian River basin?

2) How has observed warming during the period 1950 2017 affected ASM and thus extreme discharge events?

We selected the Russian River basin as our study domain because it is a coastal watershed where AR events frequently occur. Snow is rare, so the basin's response to extreme precipitation generally is not conflated with a rain-on-snow contribution. Based on observations, Ralph et al. (2006) found that all of the seven largest floods during the period 1997-2006 in this basin were due to heavy orographic precipitation caused by ARs. Topographic variations have little effect on the spatial variability of precipitation in this basin, thus avoiding the added complexity of the influence of snowmelt on streamflow that more commonly occurs in mountainous basins. Most importantly, the Russian River basin is the site of NOAA's HMT soil moisture observation network which facilitates the evaluation of model simulations.

\section{Study region}

The Russian River basin is located in Northern California. It is bounded by the Coast Range both to the east and west (see Fig. 1a). It has a drainage area of about $3850 \mathrm{~km}^{2}$ at its mouth. Elevation ranges from sea level to $1324 \mathrm{~m}$ at the top of Mount Saint Helena. It is a rain-dominant basin with basin-average midwinter (December-February) temperatures above $7.5^{\circ} \mathrm{C}$. It has dry summers and wet winters, with over $96 \%$ of the annual total precipitation (on average over our domain) falling between October and April. Annual precipitation ranged from $423 \mathrm{~mm}$ in water year (WY) 1977 to $2052 \mathrm{~mm}$ in WY 1983 with a mean of $1061 \mathrm{~mm}$ during the period 1950-2017.

The main stem of the Russian River flows southward to its confluence with Mark West Creek north of Forestville, where it turns westward and flows into the Pacific Ocean. There are two reservoirs within the basin that are operated primarily for flood control: Coyote Dam (Lake Mendocino) on the East Fork Russian River near Ukiah and Warm Springs Dam (Lake Sonoma) on Dry Creek west of Healdsburg (see Fig. 1a).

\section{Data and methods}

We first constructed an hourly gridded precipitation product for the study period. We implemented the Distributed Hydrology Soil Vegetation Model (DHSVM; Wigmosta et al. 1994) over the entire basin and ran it at an hourly time step to obtain hydrographs and ASM for historical storm events during the period WY 19502017. We identified peaks-over-threshold (POT) extreme precipitation events and extreme discharge events that were coincident with AR events. Using the hourly gridded precipitation and hourly simulated runoff and soil moisture, we investigated the role of ASM on historical AR flooding by examining the relationship between precursor soil moisture and storm runoff-precipitation 

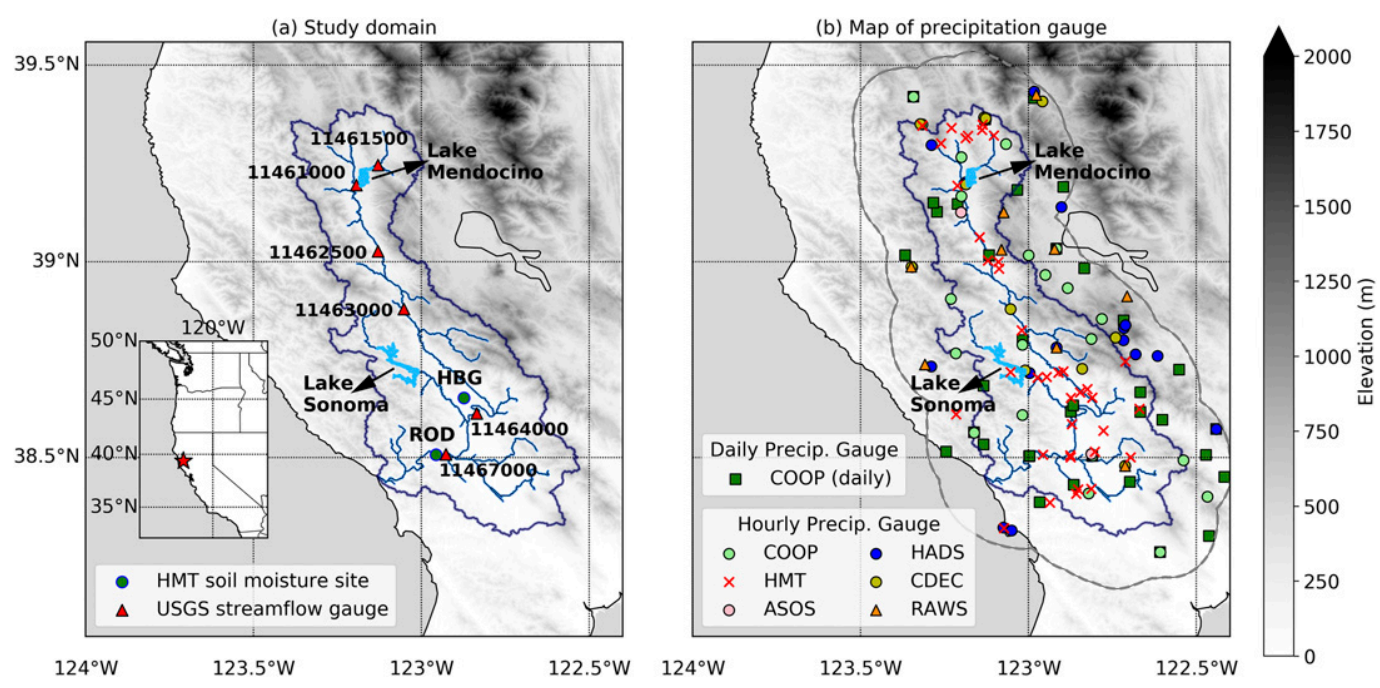

FIG. 1. (a) Study domain, with locations of USGS stream gauges and HMT soil moisture observation sites shown, and (b) precipitation gauge locations. The $15-\mathrm{km}$ buffer for the precipitation gauges selection is shown in gray dashed line in (b).

ratios. Finally, we assessed the effect of warming using the model simulations where we detrended the meteorological forcings for long-term temperature changes.

\section{a. Gridded hourly precipitation}

We derived hourly gridded precipitation data at a spatial resolution of $1 / 32^{\circ}$ for the period WY $1950-2017$. We first quality controlled the gauge data, then gridded the gauge daily precipitation, including the gauge hourly precipitation aggregated to daily, using the Mountain Mapper (MM) method (Schaake et al. 2004), and finally interpolated the gridded daily precipitation to hourly using the nearest hourly gauge.

We took daily and hourly precipitation data from NOAA's Cooperative Observer Program (COOP) network, Remote Automatic Weather Stations (RAWS), the Automated Surface Observing System (ASOS), the NOAA Hydrometeorological Automated Data System (HADS), the California Data Exchange Center (CDEC), and NOAA's Hydrometeorology Testbed (HMT). COOP stations have both hourly and daily precipitation records, some of which go back at least to WY 1950. We excluded COOP daily gauges without time of observation records. Gauges from the other networks all have hourly data with the earliest record going back to 1985 . We selected gauges within a buffer of $15 \mathrm{~km}$ from the basin and excluded gauges with overlap among different networks. We used a total of 133 gauges, including 35 COOP daily gauges, 20 COOP hourly gauges, 38 HMT gauges, 2 ASOS gauges, 18 HADS gauges, 11 CDEC gauges, and 9 RAWS gauges (see Fig. 1b).
We performed a quality control (QC) for all hourly gauges following Cao et al. (2018). After the QC, we aggregated gauge hourly precipitation to daily. We considered daily precipitation as occurring between 0000 and 2400 Pacific standard time (PST; UTC - 0800). Similarly, we used the aggregated daily data to QC the COOP daily gauges after we proportioned them to PST $24 \mathrm{~h}$ according to their observation time using the nearest hourly gauges.

We used monthly precipitation from the ParameterElevation Regressions on Independent Slopes Model (PRISM; Daly et al. 1994, 2008) as a background precipitation distribution map. Following the MM method, we calculated ratios between daily gauge precipitation and the PRISM monthly climatologies at station grid nodes. We interpolated the ratios onto the $1 / 32^{\circ}$ grids using the synergraphic mapping system (SYMAP) algorithm (Shepard 1984). Gridded daily precipitation was obtained by multiplication of the gridded ratios with the PRISM monthly climatology. Finally, we interpolated the gridded daily precipitation to hourly. For a given day in a grid cell, we first searched for the nearest precipitation gauge with complete and valid hourly data on that day, and then multiplied the hourly ratios (hourly precipitation divided by daily sum) by the daily precipitation in that grid cell.

\section{b. Model implementation}

To obtain full hydrographs of historical storm events from subdaily data and historical soil moisture conditions, we implemented the DHSVM model (Wigmosta et al. 1994) at a spatial resolution of $150 \mathrm{~m}$ over the 
entire Russian River basin and ran it at an hourly time step for the (WY) 1950 to 2017 period. Given that there were two regulated reservoirs within the basin and naturalized streamflow was needed for our analysis, we used a version of DHSVM that includes a reservoir module (DHSVM-res; Zhao et al. 2016).

\section{1) Meteorological Driving DATA}

In addition to precipitation data, DHSVM also requires meteorological inputs including air temperature, wind speed, relative humidity, and downward solar and longwave radiation at the model's hourly time step. Similar to Cao et al. (2016), we calculated the last three using the Mountain Microclimate Simulation Model (MTCLIM) algorithms as described and implemented by Bohn et al. (2013). We took wind speed data from the lowest atmospheric level in the National Centers for Environmental Prediction-National Center for Atmospheric Research (NCEP-NCAR) reanalysis output (Kalnay et al. 1996). We obtained daily maximum and minimum temperature data from 11 COOP stations with long-term temperature records. We interpolated the station temperature anomalies to a spatial resolution of $1 / 32^{\circ}$ based on the PRISM 1981-2010 climatology. Details of the gridding approach can be found in Maurer et al. (2002) and Wood and Lettenmaier (2006).

\section{2) Model evaluation data}

There are 29 USGS gauges within the basin at which instantaneous $(15 \mathrm{~min})$ streamflow records are available, with the longest record dating from October 1987. We selected six stream gauges with records longer than $\sim 30$ years for model calibration, including the upstreamand downstream-most ones (see Fig. 1a). Two upstream gauges are free of reservoir effects, while the four downstream gauges are affected by reservoir regulation. We obtained hourly reservoir storage and elevation data from CDEC, with records starting from December 1988. There are 12 HMT soil moisture sites within the basin. We selected two sites, HBG and ROD, which had the longest records (starting from December 2006). The surface layer observation was at $10 \mathrm{~cm}$ depth.

\section{3) REMOVING RESERVOIR EFFECTS FROM STREAMFLOW OBSERVATIONS}

The reservoir module divides each reservoir into an inactive pool, a conservation pool (for water supply), a flood control pool, and a surcharge pool, the elevations of which were obtained from the Sonoma County Water Agency (SCWA) for Lakes Mendocino and Sonoma. The release scheme used by DHSVM-res is based primarily on real-time water levels and predefined water demands. We estimated real-time water levels from storage through an empirical relationship based on historical CDEC records. Similarly, we estimated the real-time surface area (for the calculation of reservoir evaporation) from storage as based on CDEC storage observations and historical surface area time series from Landsat data.

We evaluated the model simulations of streamflow at gauges throughout the basin and simulations of reservoir storage. We then calculated the difference of simulated streamflow without and with the reservoir module at each stream gauge affected by the reservoir regulations. We then added the difference back to the observed streamflow in order to create an estimate of naturalized flows.

\section{c. AR-related POT extreme events}

We used the POT method to select extreme events, which samples observations above a given threshold value and considers a wider range of events than the block maxima approach (e.g., Lang et al. 1999; Begueria et al. 2011; Mallakpour and Villarini 2017). We first selected POT extreme precipitation events and POT extreme discharge events separately based on daily observations. We then identified the extreme events that were coincident with AR events.

\section{1) EXTREME PRECIPITATION EVENTS}

For the six long-term stream gauges on which we focused, we calculated the daily precipitation at each averaged over its upstream drainage area. We selected POT extreme precipitation events based on daily precipitation data. We defined events based on consecutive days with peak daily precipitation exceeding a given threshold. We selected thresholds to result in 1, 2, 3, 5, and 7 events per year on average, which we denote as $\mathrm{POT}_{\mathrm{N} 1}, \ldots, \mathrm{POT}_{\mathrm{N} 7}$. Events were separated from each other by at least one day with daily precipitation below the threshold value, as in Mondal and Mujumdar (2015).

We used the 6-hourly AR catalog of Gershunov et al. (2017), who applied an AR detection method based on both IWV and IVT to the NCEP-NCAR reanalysis data, starting with 1948. Ralph et al. (2019b) evaluated the performance of a diverse set of AR detection tools (ARDTs) in the Russian River basin in comparison with the local AR observatory, including the three applied to the NCEP-NCAR dataset: Rutz et al. (2014), Guan and Waliser (2015), and Gershunov et al. (2017). The three tools had similar parameters and geometric characteristics and hence showed similar performance in capturing AR frequency, duration, and intensity. All three tools inferred slightly higher AR contribution to precipitation compared with other ARDTs (Ralph et al. $2019 b)$ due to their less stringent geometric criteria. 
TABLE 1. Streamflow [cubic meters per second $(\mathrm{cms})$ ] and reservoir storage calibration statistics. DA is drainage area and KGE is the Kling-Gupta efficiency. All statistics are for hourly data. The unit of RMSE and bias for reservoir storage is in million cubic meters and the unit for reservoir elevation is in meters.

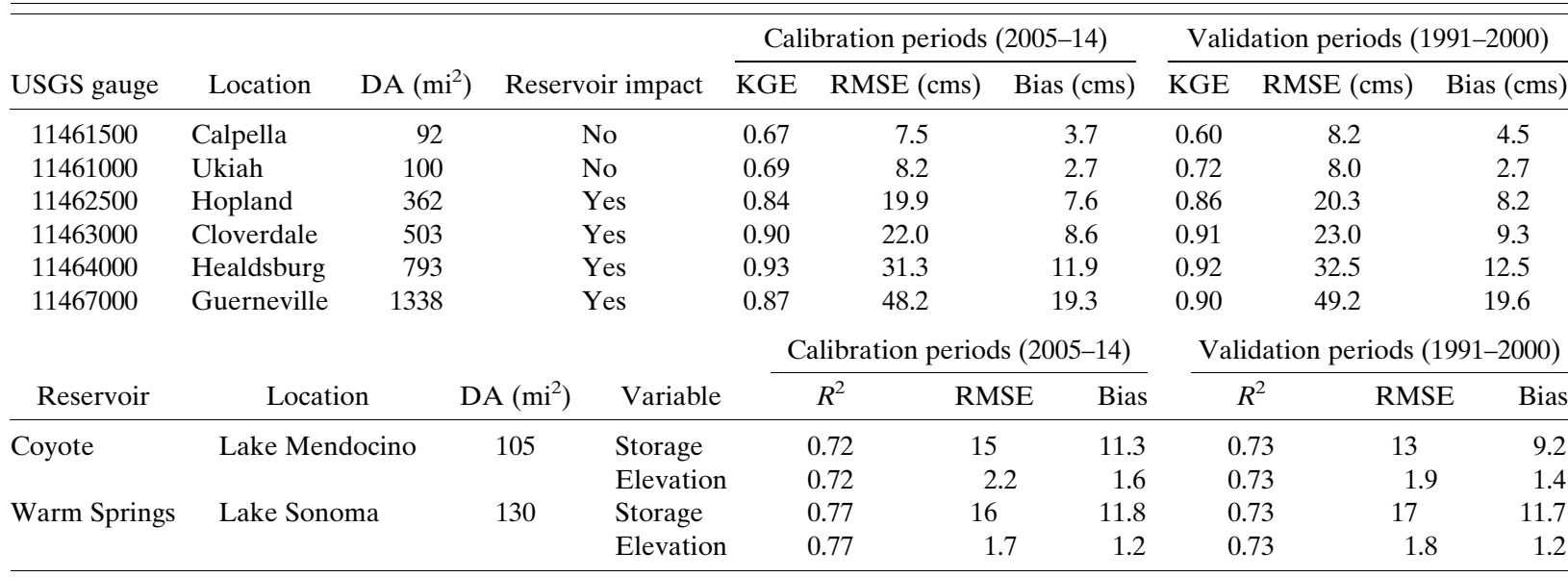

We used the AR catalog of Gershunov et al. (2017) primarily because it spans the entire period of the NCEPNCAR reanalysis up to near-real time. We extracted the NCEP-NCAR grid cells (at a relatively coarse $2.5^{\circ}$ spatial resolution) that intersected the Russian River basin and identified landfalling ARs. We examined the intersection of AR events from this catalog and POT extreme precipitation events identified as above.

\section{2) EXTREME DischaRge EVENTS}

For the selection of POT extreme discharge events, we first applied the independence criteria from the U.S. Water Resources Council (USWRC 1982) to daily streamflow. According to these criteria the second flood peak of two consecutive events must be rejected if

$N_{\text {interval }}<5$ days $+\log (A)$ or $X_{\min }<(3 / 4) \times \min \left[Q_{1}, Q_{2}\right]$

where $N_{\text {interval }}$ is the number of interval days between two peaks, $A$ is the basin area in square miles, $X_{\min }$ is the minimum intermediate flow between two peaks, and $Q_{1}$ and $Q_{2}$ are two consecutive peak values. Same as extreme precipitation events, we set thresholds for the observed daily streamflow at each gauge after removing the reservoir effect to result in 1, 2, 3, 5, and 7 extreme discharge events per year on average.

\section{3) ESTIMATION OF STORM RUNOFF RATIOS}

The selections of POT extreme precipitation events and extreme discharge events were both based on daily observations. However, we needed the subdaily data for the full hydrographs in order to estimate storm runoff ratios. Hence, we calculated the runoff ratios using hourly gridded precipitation from observations and hourly runoff from model simulations (readily available hourly discharge observations are too short for a period to be useful).

For each POT extreme precipitation event, we calculated its runoff ratio, which is equal to the storm total runoff volume divided by storm total precipitation. We took the beginning of a precipitation event as the first hour with precipitation greater than $0.3 \mathrm{~mm}$ (to avoid small spikes in COOP hourly data). The event ends once the hourly precipitation becomes lower than $0.3 \mathrm{~mm}$ or when the AR event ends, if it is one, and exceeds the first criterion. The summation of precipitation over the event hours is the storm total precipitation. For a runoff event, we determined the start and end of events in the hourly simulated streamflow as follows:

1) An event starts with the rise of the hydrograph.

2) If there is no following event, the end of the event is determined using the constant $k$ method of Blume et al. (2007), in which $k$ is the recession coefficient, but no longer than three days after the peak hour.

3) If there is an immediate following event before the end of this event, the event ends with the start of the following one.

The summation of streamflow over the event hours is the storm total runoff. The estimated runoff ratio of a storm event may be larger than 1.0 since we did not separate the baseflow from the streamflow time series, and the criteria we used to determine the start and end of individual events might not be sophisticated enough for time series at such a high (i.e., hourly) temporal resolution especially for small storm events. To take $\mathrm{POT}_{\mathrm{N} 3}$ events as an example, runoff ratios larger than 1 occurred less 
(a) HBG site
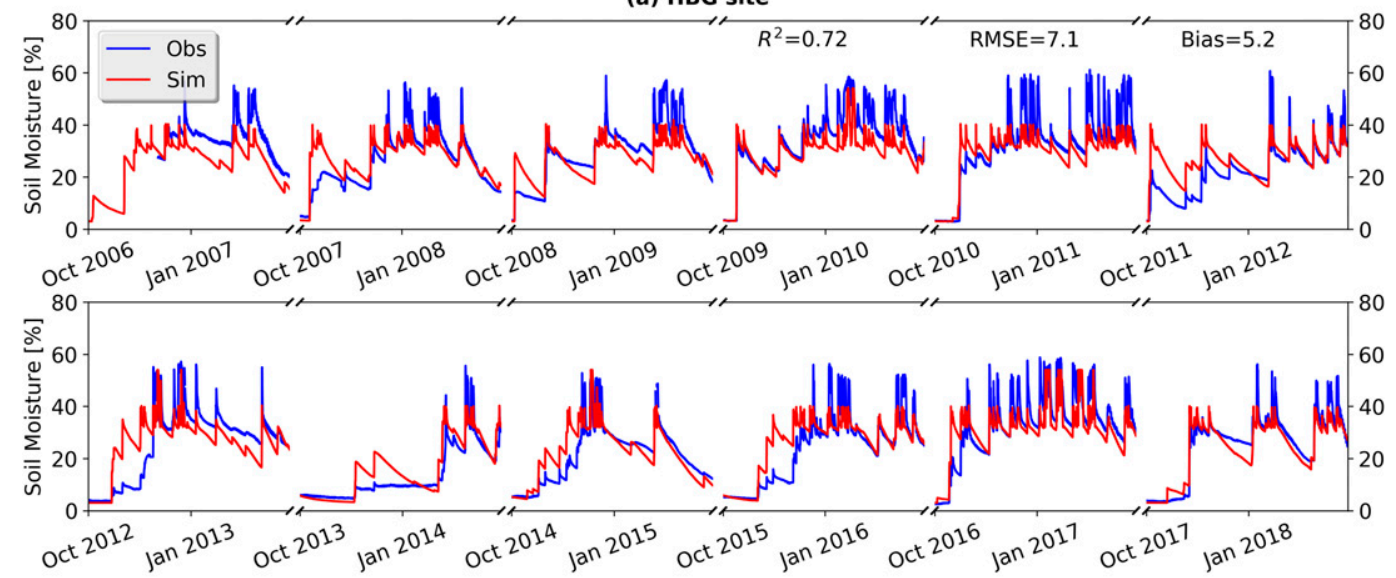

(b) ROD site
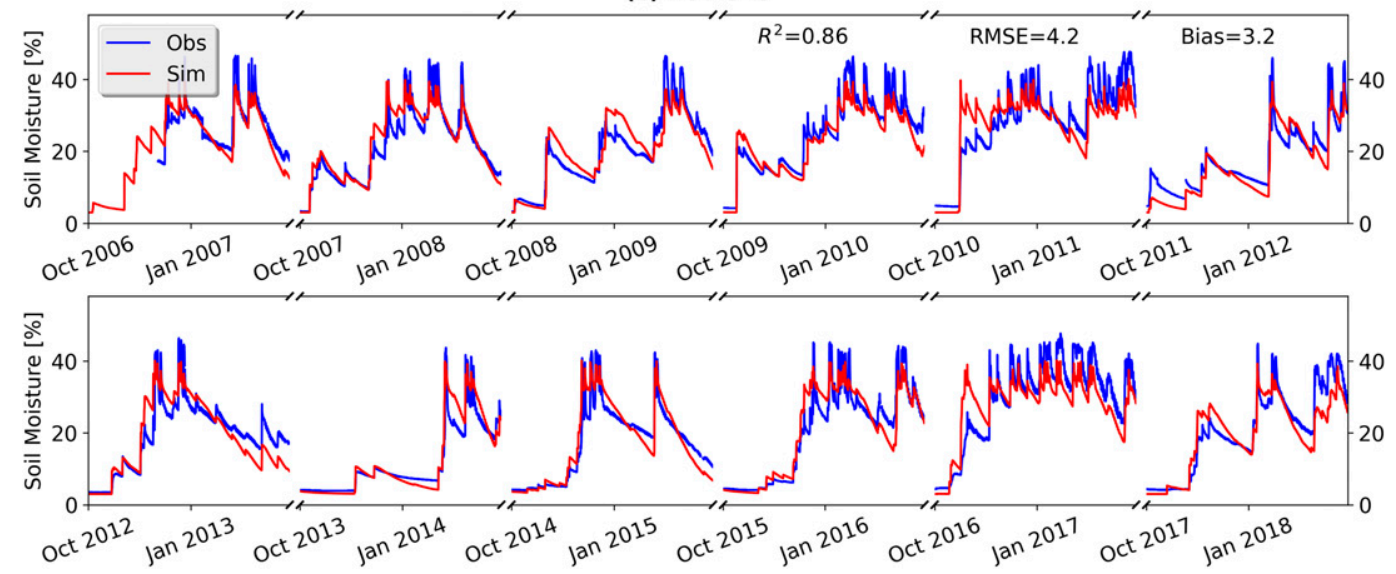

FIG. 2. Comparison of simulated and observed surface-layer soil moisture at (a) HBG and (b) ROD sites during late fall and winter months (October-March) of WY 2007-17. The simulation is from the 150-m (model spatial resolution) pixel nearest to the observation site.

than $10 \%$ and $15 \%$ of the time at downstream and upstream gauges, respectively. The ASM is defined as the minimum value of the hourly surface-layer soil moisture within the $24 \mathrm{~h}$ prior to the start of a precipitation event.

\section{d. Examination of warming effect}

The domain-average annual daily maximum temperature $\left(T_{\max }\right)$ and daily minimum temperature $\left(T_{\min }\right)$ increased by $0.8^{\circ}$ and $1.3^{\circ} \mathrm{C}$ respectively from 1950 to 2017 , determined by linear regression. The $T_{\min }$ generally increased over the entire domain in all seasons, with slight decreases during fall and winter months in the southwestern part, while $T_{\max }$ generally increased over the southern half of the domain and slightly decreased in the northern part especially during summer and fall months (see Fig. S1 in the online supplemental material).

To evaluate the effect of temperature change on ASM and floods since 1950, we constructed scenarios representing the temperature conditions in 1950 and
2017. Following Hamlet and Lettenmaier (2007), we detrended the temperature time series for each $1 / 32^{\circ}$ grid cell and each calendar month by removing the linear trends in the monthly average $T_{\max }$ and $T_{\min }$ over the period of WY 1950-2017 relative to the pivot year 1950 (denoted as "T1950") and 2017 (denoted as "T2017") based on the following equation:

$$
\begin{aligned}
T_{\text {adj }}[\text { month }][\text { year }]= & T_{\text {orig }}[\text { month }][\text { year }]+\text { Trend }[\text { month }] \\
& \times(\text { pivot_year }- \text { year }) .
\end{aligned}
$$

Under both scenarios, we assume that precipitation is not affected by temperature and stays unchanged. By comparing the ASM and flood response between the scenarios T1950 and T2017, we evaluate the impact of temperature increases without the influence of precipitation change over the past 68 years. 


\section{Results}

\section{a. Model evaluation}

We first assessed the precipitation gridding method. We then evaluated the model performances for reservoir storage, streamflow, storm total runoff volume, and soil moisture. We also compared the composite time series of hourly streamflow during extreme precipitation events. We summarize each of these evaluations below.

\section{1) GRIDDED PRECIPITATION}

We assessed the accuracy of the precipitation gridding method by systematically removing individual stations within the basin one at a time and evaluating the gridded product at the station grid in comparison with the removed station following Cao et al. (2018). The predicted precipitation at station locations showed reasonable matches with the available observations during the period WY 1950-2017, with the coefficient of determination $\left(R^{2}\right)$ ranging from 0.83 to 1.0 and root-mean-square error (RMSE) ranging from 0.3 to $6.5 \mathrm{~mm} \mathrm{day}^{-1}$ (mostly smaller than $3 \mathrm{~mm} \mathrm{day}^{-1}$; see Fig. S2).

\section{2) STREAMFLOW AND STORM TOTAL RUNOFF VOLUME}

We evaluated model performance for reservoir storage using $R^{2}$, RMSE, and bias. For the hourly storage calibration, the $R^{2}$ values were 0.72 and 0.77 , the RMSEs were 15.0 and 16.0 million $\mathrm{m}^{3}$, and the biases were 11.3 and 11.8 million $\mathrm{m}^{3}$ for Lake Mendocino and Lake Sonoma, respectively (see Table 1 and Fig. S3). In terms of elevation, the RMSEs were 2.2 and $1.7 \mathrm{~m}$, and the biases were 1.6 and $1.2 \mathrm{~m}$, respectively. Model performance in the validation periods was similar to the calibration periods at Lake Mendocino but slightly degraded at Lake Sonoma.

We used the Kling-Gupta efficiency (KGE; Gupta et al. 2009), RMSE, and bias to evaluate the goodnessof-fit between hourly streamflow observations and hourly simulations at the six selected stream gauges throughout the basin (see Fig. 1a for gauge location). The simulations at gauges affected by reservoir regulations were from the model runs with the reservoir module activated. For the calibration period, the KGE ranged from 0.67 to 0.93 , the RMSE ranged from 7.5 to $48.2 \mathrm{cms}$, and the bias ranged from 2.7 to $19.3 \mathrm{cms}$ (see Table 1 and Fig. S4). Model performance in the validation periods was similar to the calibration periods. The KGE was the highest at the downstream gauge 11464000.

In addition, we compared the observed (with reservoir effects removed) and simulated storm total runoff volumes calculated from the hourly data at six stream gauges for $\mathrm{POT}_{\mathrm{N} 3}$ (three events per year on average) extreme

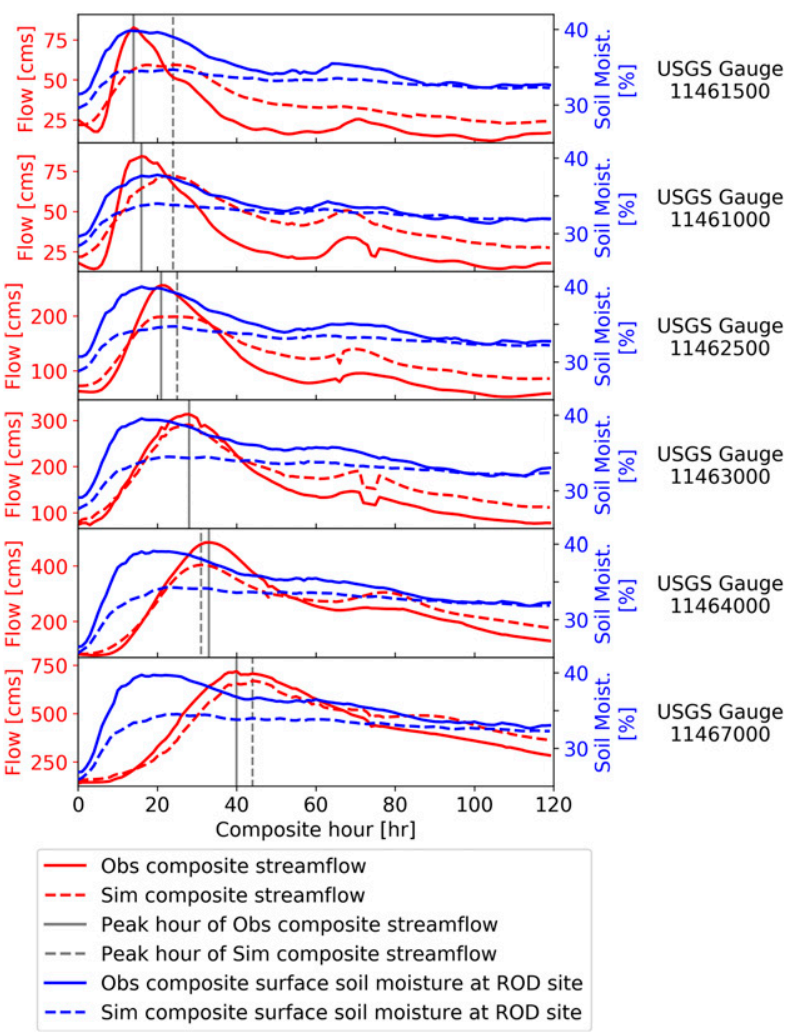

FIG. 3. Composite time series of observed and simulated hourly streamflow and surface-layer soil moisture at ROD site of $\mathrm{POT}_{\mathrm{N} 3}$ extreme precipitation events during WY 2007-17 at six USGS stream gauges ranked by drainage area. Peak hours of the composite observed and simulated streamflow are shown in gray solid line and gray dashed line, respectively.

precipitation events during WY 1988-2017, which is the period when there were available observations for hourly streamflow (see Fig. S5). The $R^{2}$ ranged from 0.68 to 0.95 , with better match downstream.

\section{3) SOIL MOISTURE}

We evaluated the model performance of surfacelayer soil moisture simulations at the HBG and ROD sites using $R^{2}$, RMSE, and bias (see Fig. 2). For hourly soil moisture, the $R^{2}$ values were 0.72 and 0.86 , the RMSEs were $7.1 \%$ (volumetric water content) and $4.2 \%$, and the biases were $5.2 \%$ and $3.2 \%$ for $\mathrm{HBG}$ and ROD, respectively, during late fall and winter months (October-March) from WY 2007 to WY 2017, the period when there were available observations.

\section{4) Peak hour of Streamflow}

Figure 3 shows the composite time series of $\mathrm{POT}_{\mathrm{N} 3}$ extreme precipitation events during WY 2007-17. The simulated hourly streamflow showed reasonable matches with the observed hourly streamflow at downstream gauges. 
(a) USGS Guage 11461500

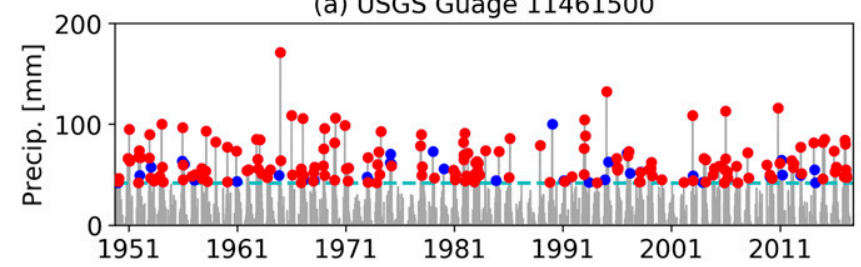

(c) USGS Guage 11462500

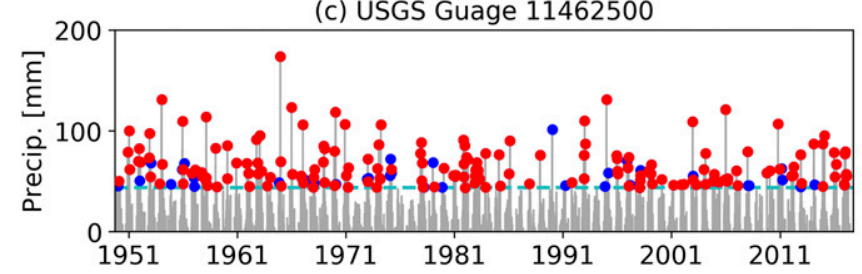

(e) USGS Guage 11464000

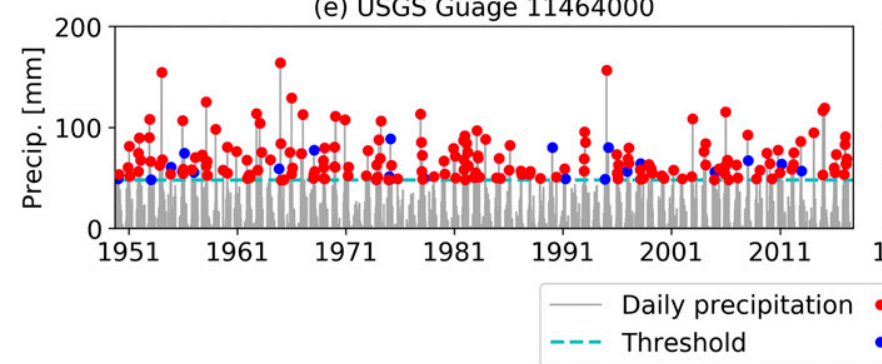

(b) USGS Guage 11461000

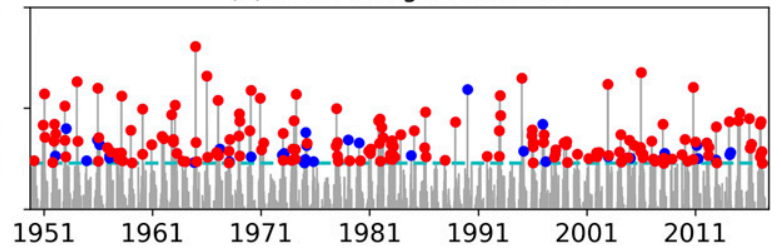

(d) USGS Guage 11463000

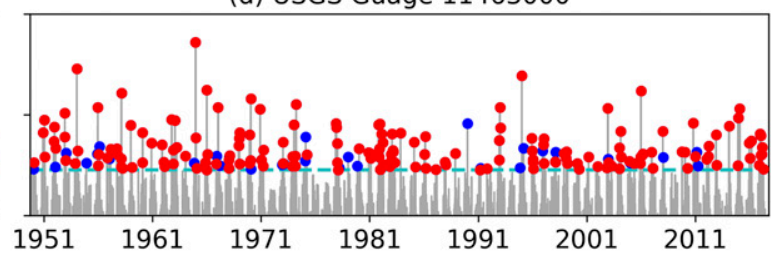

(f) USGS Guage 11467000

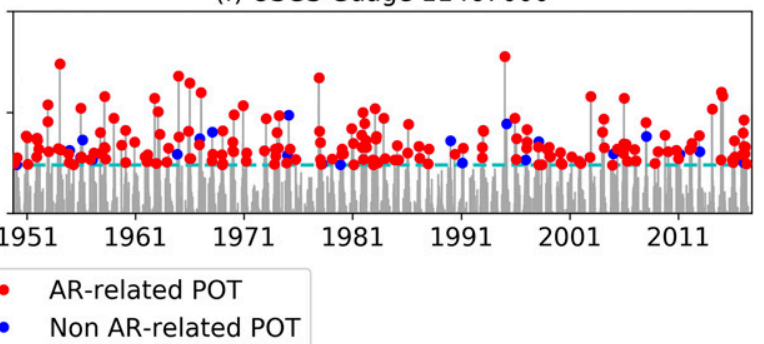

FIG. 4. $\mathrm{POT}_{\mathrm{N} 3}$ extreme precipitation events (with threshold set to three events per year on average) based on gridded daily precipitation averaged over the upstream drainage area at six USGS stream gauges during WY 1950-2017.

However, its performance was not as good at upstream gauges, which have relatively small drainage areas and where the simulated streamflow arguably is more sensitive to the quality of the precipitation forcings than at downstream gauges. Furthermore, there are very few long-term precipitation gauges in the headwater areas. The peak hour of observed streamflow gradually increased from $14 \mathrm{~h}$ at the upstream-most gauge (11461500) to $40 \mathrm{~h}$ at the downstream-most gauge (11467000). The simulated streamflow showed the best match for peak hour at gauge (11463000) in the middle of the basin.

\section{b. The role of $A R$ in extreme events}

We set thresholds of POT extreme precipitation events to make sure there were $1,2,3,5$, and 7 events per year on average. Figure 4 shows the POT extreme precipitation events when the threshold was set to three events per year at six stream gauges from upstream-most to downstreammost throughout the basin during WY 1950-2017, in which most of the events were AR related. Table 2 summarizes the percentage of events that are related to ARs with different threshold values. We can see that the percentage of AR-related precipitation events increased as the threshold increased. The AR contribution increased (from $81.9 \%-83.0 \%$ with a mean of $82.5 \%$ to $95.6 \%-100.0 \%$ with a mean of $98.8 \%$ ) across the gauges when the threshold increased from $\mathrm{POT}_{\mathrm{N} 7}$ to $\mathrm{POT}_{\mathrm{N} 1}$. Also, no more than one non-AR-related POT event across six gauges was in the upper 25th percentile of all extreme precipitation events when the threshold was higher than three events per year. Even when the threshold was set to five or seven events per year, no more than four of them fell into the upper 25th percentile (see Table 2). The median (peak) precipitation of ARrelated POT extreme precipitation events was greater than non AR-related events by $7.8 \%-23.2 \%$ across six gauges with a threshold of $\mathrm{POT}_{\mathrm{N} 3}$ and by $23.1 \%-34.9 \%$ with a threshold of $\mathrm{POT}_{\mathrm{N} 7}$ (see Table S1).

We set the same thresholds for POT extreme discharge events. The AR contribution increased from $59.9 \%-69.7 \%$ with a mean of $65.6 \%$ to $91.2 \%-97.1 \%$ with a mean of $94.9 \%$ across the gauges when the threshold increased from $\mathrm{POT}_{\mathrm{N} 7}$ to $\mathrm{POT}_{\mathrm{N} 1}$. No more than one non AR-related POT event across six gauges was in the upper 25th percentile of all extreme discharge events when the threshold was higher than two events per year (see Table 2). The median (peak) discharge of AR-related POT extreme discharge events was greater than non-AR-related events by $34.6 \%-$ $44.8 \%$ across six gauges with a threshold of $\mathrm{POT}_{\mathrm{N} 3}$ and by $80.0 \%-213.2 \%$ with a threshold of $\mathrm{POT}_{\mathrm{N} 7}$ (see Table S1). 
TABLE 2. Statistics of POT extreme precipitation and discharge events at six USGS stream gauges. Variable $N$ is the number of events and $N_{\text {upper25th }}$ is the number of events in the upper 25 th percentile.

\begin{tabular}{|c|c|c|c|c|c|c|c|}
\hline \multirow[b]{2}{*}{ POT extreme precipitation events } & \multirow{2}{*}{$\begin{array}{l}\text { Threshold } \\
\left(N \mathrm{yr}^{-1}\right)\end{array}$} & \multicolumn{6}{|c|}{ USGS stream gauge } \\
\hline & & 11461500 & 11461000 & 11462500 & 11463000 & 11464000 & 11467000 \\
\hline \multirow{5}{*}{ AR-related percentage (\%) } & 1 & 100.0 & 100.0 & 100.0 & 100.0 & 97.1 & 95.6 \\
\hline & 2 & 96.3 & 95.6 & 97.1 & 96.3 & 96.3 & 94.9 \\
\hline & 3 & 91.7 & 93.1 & 92.6 & 93.6 & 94.6 & 95.6 \\
\hline & 5 & 86.5 & 88.5 & 87.1 & 87.6 & 86.8 & 87.4 \\
\hline & 7 & 81.9 & 83.0 & 82.6 & 83.0 & 82.1 & 82.6 \\
\hline \multirow[t]{6}{*}{$N_{\text {upper25th }}(\mathrm{AR} /$ non-AR $)$} & 1 & $17 / 0$ & $17 / 0$ & $17 / 0$ & $17 / 0$ & $17 / 0$ & $17 / 0$ \\
\hline & 2 & $34 / 0$ & $34 / 0$ & $34 / 0$ & $34 / 0$ & $34 / 0$ & $34 / 0$ \\
\hline & 3 & $51 / 0$ & $51 / 0$ & $51 / 0$ & $51 / 0$ & $50 / 1$ & $50 / 1$ \\
\hline & 5 & $84 / 1$ & $85 / 0$ & $85 / 0$ & $84 / 1$ & $83 / 2$ & $82 / 3$ \\
\hline & 7 & $115 / 4$ & $116 / 3$ & $116 / 3$ & $116 / 3$ & $115 / 4$ & $115 / 4$ \\
\hline & Threshold & \multicolumn{6}{|c|}{ USGS stream gauge } \\
\hline POT extreme discharge events & $\left(N \mathrm{yr}^{-1}\right)$ & 11461500 & 11461000 & 11462500 & 11463000 & 11464000 & 11467000 \\
\hline \multirow[t]{5}{*}{ AR-related percentage (\%) } & 1 & 95.6 & 92.6 & 95.6 & 97.1 & 97.1 & 91.2 \\
\hline & 2 & 90.4 & 94.9 & 92.6 & 93.4 & 93.4 & 85.3 \\
\hline & 3 & 83.9 & 88.8 & 88.2 & 88.7 & 88.7 & 80.4 \\
\hline & 5 & 75.3 & 78.8 & 73.2 & 74.4 & 73.5 & 68.5 \\
\hline & 7 & 69.0 & 69.7 & 65.5 & 65.1 & 64.3 & 59.9 \\
\hline \multirow[t]{5}{*}{$N_{\text {upper25th }}(\mathrm{AR} /$ non-AR $)$} & 1 & $17 / 0$ & $17 / 0$ & $17 / 0$ & $17 / 0$ & $17 / 0$ & $17 / 0$ \\
\hline & 2 & $33 / 1$ & $33 / 1$ & $34 / 0$ & $34 / 0$ & $34 / 0$ & $33 / 1$ \\
\hline & 3 & $48 / 3$ & $49 / 3$ & $51 / 0$ & $51 / 0$ & $51 / 0$ & $45 / 6$ \\
\hline & 5 & $79 / 6$ & $80 / 5$ & $78 / 7$ & $81 / 4$ & $81 / 4$ & $75 / 10$ \\
\hline & 7 & $110 / 9$ & $113 / 6$ & $110 / 9$ & $112 / 7$ & $112 / 7$ & $104 / 15$ \\
\hline
\end{tabular}

\section{c. The role of ASM in historical AR flooding}

\section{1) EXTREME PRECIPITATION EVENTS}

\section{(i) Observation-based examination}

We examined the relationship between the ASM and runoff ratio in the $\mathrm{POT}_{\mathrm{N} 3}$ extreme precipitation events based on observations at six stream gauges throughout the basin during WY 2007-17 (the period when hourly soil moisture observations were available at two of the HMT sites and hourly streamflow observations were available at USGS gauges). Following Crow et al. (2017), we used the Spearman rank correlation coefficient $R_{s}$ to evaluate the strength of the potentially nonlinear relationship between ASM and the runoff ratio. Figure 5a shows the observed runoff ratio versus the observed ASM at the ROD site. The $R_{s}$ values generally were higher at downstream gauges than upstream gauges, ranging from 0.71 to 0.82 , with the highest value at the downstream-most gauge 11467000 . A similar pattern was found for the relationships between the simulated runoff ratio and simulated ASM at the ROD site, with $R_{s}$ ranging from 0.76 to 0.88 (see Fig. 5b). Similarly, the ranges of $R_{s}$ for the observation versus observation and model versus model comparisons at the HBG site are 0.630.75 and $0.55-0.73$, respectively (see Figs. $5 \mathrm{c}$, d).

Relatively long soil moisture observation records were available only at the HBG and ROD sites; however, we simulated soil moisture for the entire basin. For each stream gauge, we calculated the average ASM over its upstream drainage area. The $R_{s}$ between simulated runoff ratios and simulated upstream average ASM ranged from 0.78 to 0.91 , higher than the above $R_{s}$ values calculated based on ASM at one single site (see Fig. 5e). The $R_{s}$ across gauges generally increased as drainage area increased. Besides, the $\mathrm{POT}_{\mathrm{N} 3}$ extreme precipitation events followed by $\mathrm{POT}_{\mathrm{N} 1}$ extreme discharge events generally had a wet prestorm condition (see Fig. 5e). Also, the top $\mathrm{POT}_{\mathrm{N} 1}$ extreme discharge events were all related to ARs during WY 2007-17.

\section{(ii) Simulation-based examination}

Given that the model produced plausible reproductions of observed streamflow and soil moisture, we examined the relationship between the ASM and runoff ratio in the $\mathrm{POT}_{\mathrm{N} 3}$ extreme precipitation events related to ARs based on simulated hourly streamflow and simulated hourly soil moisture at six stream gauges throughout the basin during WY 1950-2017. Figure 6 shows boxplots of the simulation-based runoff ratios versus possible influencing factors including maximum precipitation intensity, average precipitation intensity, storm total precipitation and ASM. The plots show that runoff ratio was barely affected by either the maximum or average precipitation intensity (see Figs. 6a,b). It 
(a) Obs runoff ratio vs. Obs ASM at ROD site

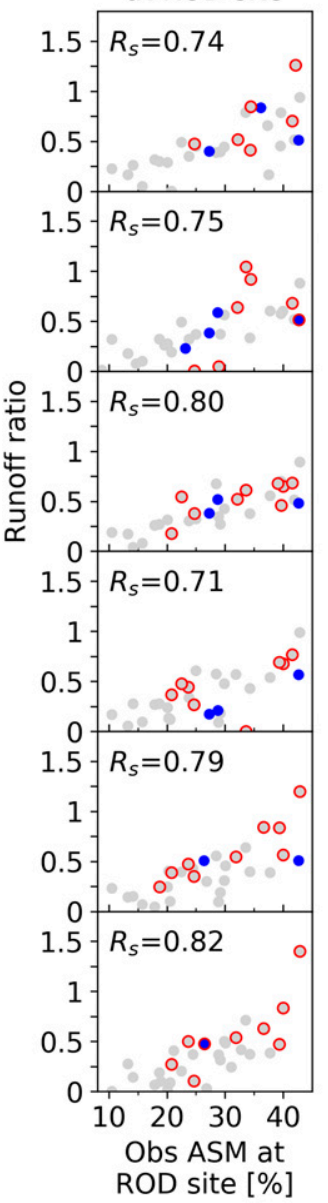

(b) Sim runoff ratio vs. Sim ASM at ROD site

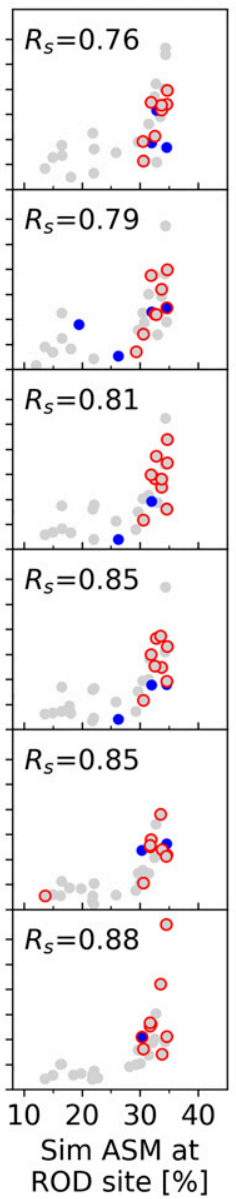

(c) Obs runoff ratio vs. Obs ASM at HBG site

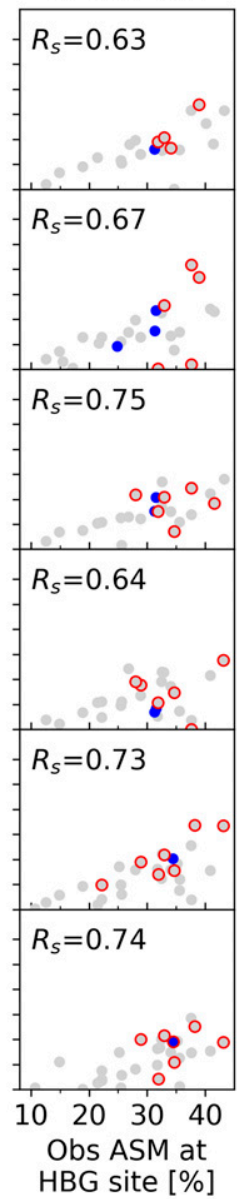

(d) Sim runoff ratio (e) Sim runoff ratio vs. Sim ASM vs. Sim upstream at HBG site

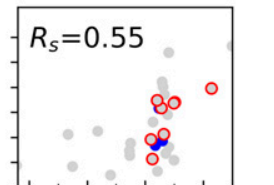

$R_{s}=0.58$

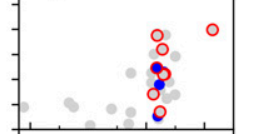

$R_{s}=0.61$

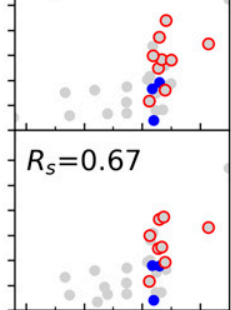

$R_{s}=0.58$

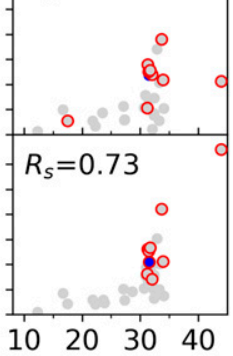

Sim ASM at HBG site [\%]
vS. Sim upstream
ave. ASM

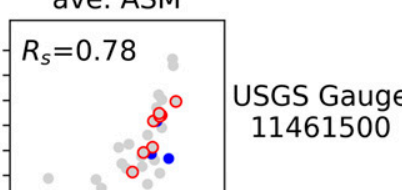

USGS Gauge 11461000

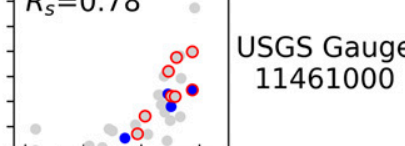

$R_{s}=0.85$
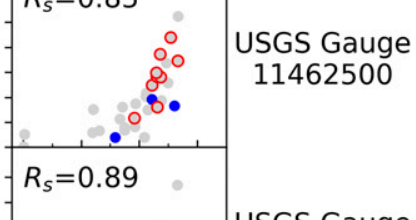
11463000

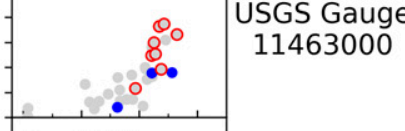

$R_{S}=0.85$

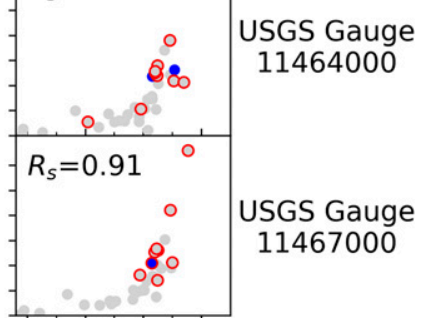

$\begin{array}{llll}10 & 20 & 30 & 40\end{array}$

Sim ASM averaged over drainage area [\%]

\section{AR-related POT P3 $_{3}$ extreme precipitation events \\ - $\quad$ Non AR-related POT N3 $_{3}$ extreme precipitation events \\ - Extreme precipitation events followed by POT $_{N 1}$ extreme discharge events}

FIG. 5. Comparison of the observation-based and simulation-based relationships between runoff ratio and ASM of POT $\mathrm{N3}$ extreme precipitation events (with threshold set to three events per year on average) during WY 2007-17 (period of available soil moisture observations) at six USGS stream gauges ranked by drainage area, including (a) observed runoff ratio vs observed ASM at ROD site; (b) simulated runoff ratio vs simulated ASM at ROD site; (c),(d) as in (a),(b), but at HBG site; and (e) simulated runoff ratio vs simulated ASM averaged over upstream drainage area of the stream gauge. The observed runoff ratio is calculated based on gridded hourly precipitation and observed hourly streamflow with reservoir effects removed. The simulated runoff ratio is calculated based on gridded hourly precipitation and simulated hourly streamflow.

generally increased, in terms of the median value, as storm total precipitation increased, but with a wide range regardless of the total precipitation (Fig. 6c).

In contrast, the runoff ratio is much more strongly related to ASM, with $R_{s}$ increasing slightly from 0.78 at upstream gauge 11461000 to 0.86 at downstream gauge 11467000 for all $\mathrm{POT}_{\mathrm{N} 3}$ extreme precipitation events (Fig. 6d). When ASM was in the lower 20th percentile, the runoff ratios were low regardless of precipitation intensity. ASM, however, had a smaller effect on the runoff ratios as storm total precipitation increased, especially at downstream gauges (Fig. 6c).

To compare the relationship between the ASM and runoff ratio for AR- and non-AR events, we set the threshold lower to include more events, so that we have enough non-AR events to get reasonable statistics. We set the threshold of POT extreme precipitation events to make sure there were 10 events per year on average. For 680 POT extreme precipitation events during the period WY 1950-2017, there were 506-515 AR events 
(a) Sim runoff ratio vs.

Obs storm max. precip.

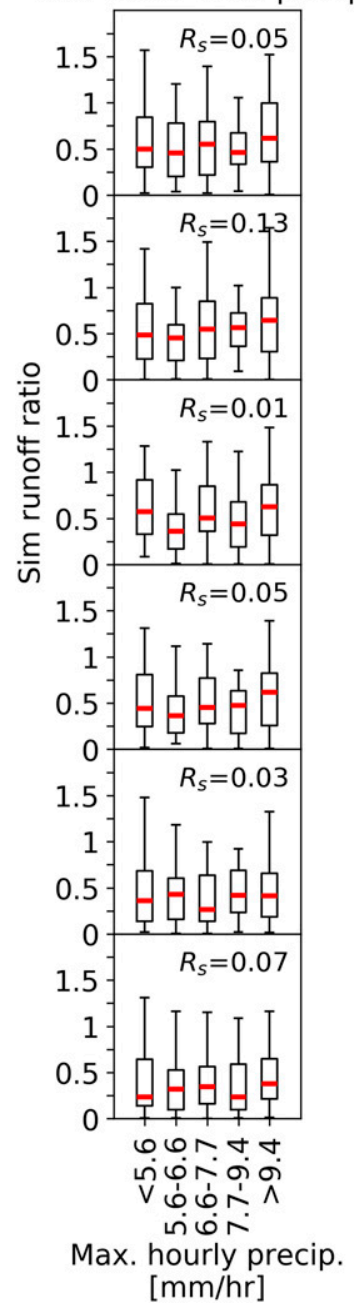

(b) Sim runoff ratio vs.

Obs storm ave. precip.

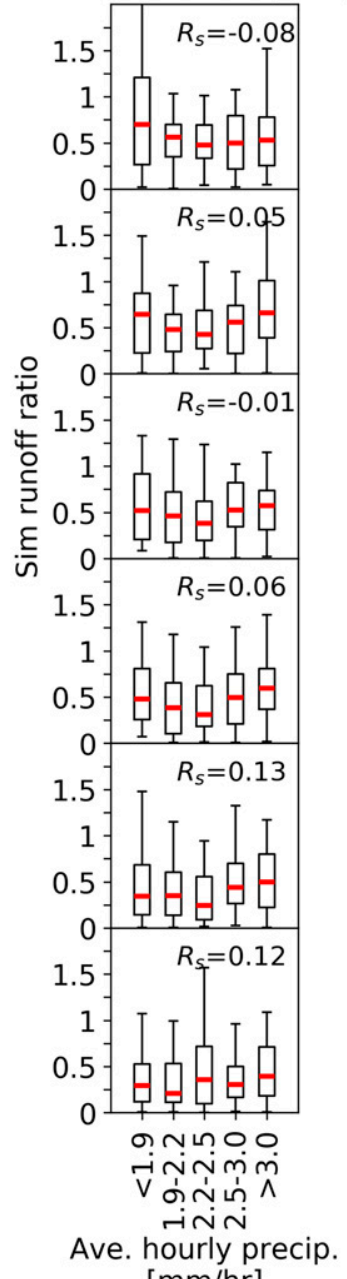

(c) Sim runoff ratio vs.

Obs storm total precip.
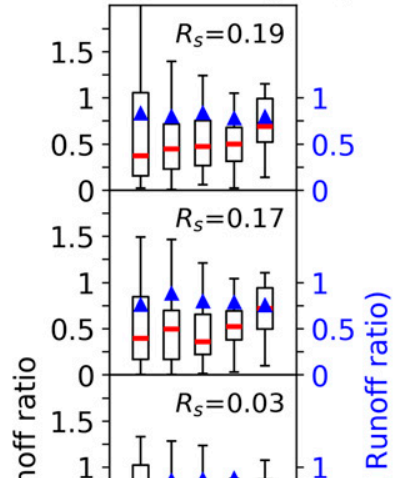

赔

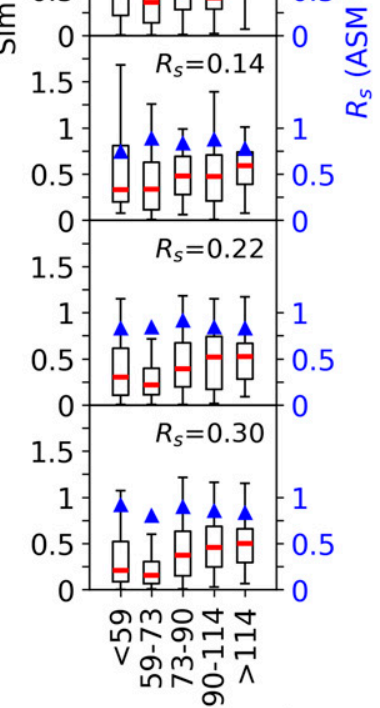

Storm total precip. [mm] (d) Sim runoff ratio vs.

Sim upstream ave. ASM

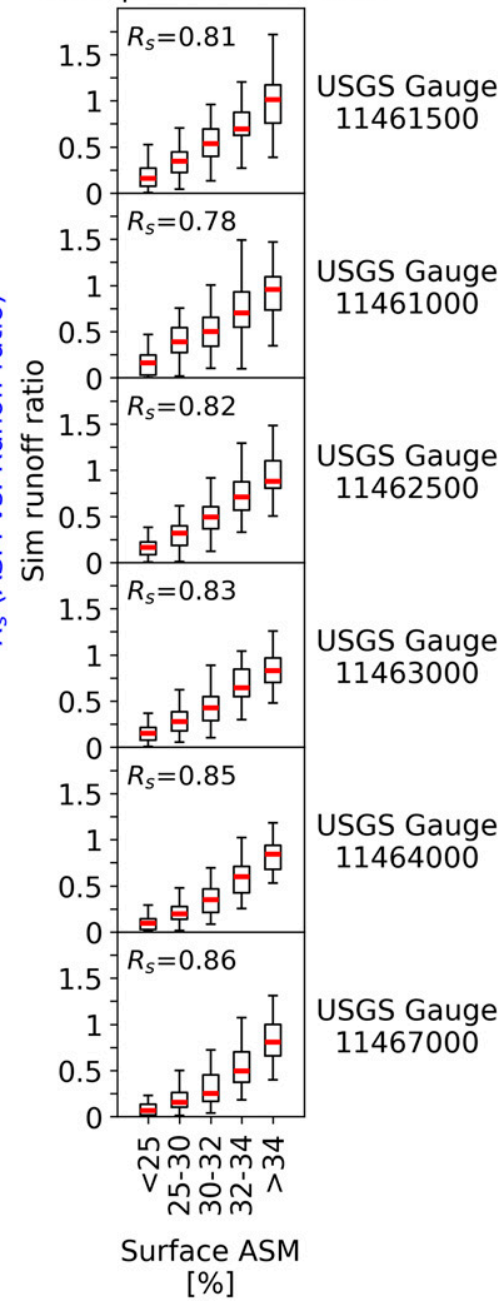

FIG. 6. Boxplots with an interval of 20th percentile of the simulation-based runoff ratio vs the (a) maximum precipitation intensity, (b) average precipitation intensity, (c) storm total precipitation, and (d) ASM of POT $_{\mathrm{N} 3}$ extreme precipitation events (with threshold set to three events per year on average) during WY 1950-2017 at six USGS stream gauges ranked by drainage area. The Spearman's rank coefficient $\left(R_{s}\right)$ between the runoff ratio and ASM vs the storm total precipitation is shown as blue triangles in (c).

and 165-174 non-AR ones across six gauges. The runoff ratio was generally higher for AR events than non-AR events given the same threshold of ASM since storm precipitation was generally larger for AR events (see Fig. 7).

\section{2) EXTREME DiSCHARGE EVENTS}

Our analysis above shows that extreme precipitation events lead to extreme discharge events when ASM is wet or when storm total precipitation is large enough (see section 5 for more discussion). In this section, we examine the relationship between the ASM, storm precipitation and peak daily flow in the $\mathrm{POT}_{\mathrm{N} 1}, \mathrm{POT}_{\mathrm{N} 2}$, and $\mathrm{POT}_{\mathrm{N} 3}$ extreme discharge events based on observed daily streamflow and simulated hourly soil moisture at six stream gauges throughout the basin during WY 1950-2017.

First, we examined the relationship between accumulated storm precipitation and observed peak daily flow given antecedent soil moisture. We used durations ranging from 6 to $72 \mathrm{~h}$ since the start of storm precipitation during each extreme discharge event so that we could determine which duration of precipitation most strongly affects the peak flow (see Fig. 8 for results). The correlation generally increased as duration increased and peaked around $48 \mathrm{~h}$ for most gauges in $\mathrm{POT}_{\mathrm{N} 2}$ and $\mathrm{POT}_{\mathrm{N} 3}$ events. The correlation peaked at a longer duration for some gauges in $\mathrm{POT}_{\mathrm{N} 1}$ events. For consistency, we used the first 2-day (48-h) accumulated storm precipitation (denoted as $\mathrm{SP}_{2 \mathrm{~d}}$ ) in the analysis described below. 
(a) USGS Gauge 11461500

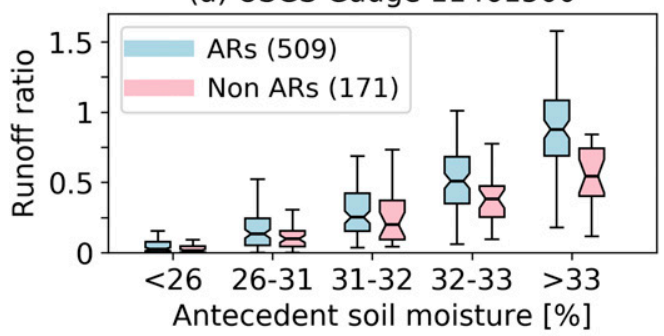

(c) USGS Gauge 11462500

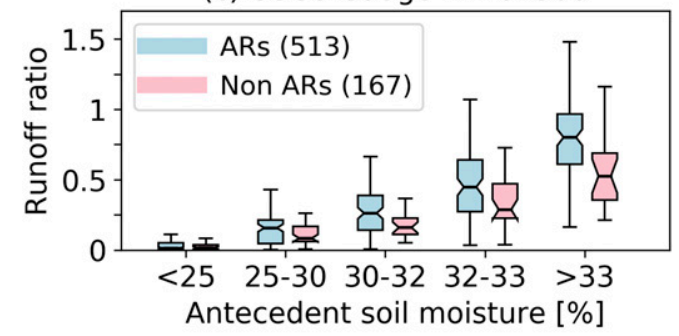

(e) USGS Gauge 11464000

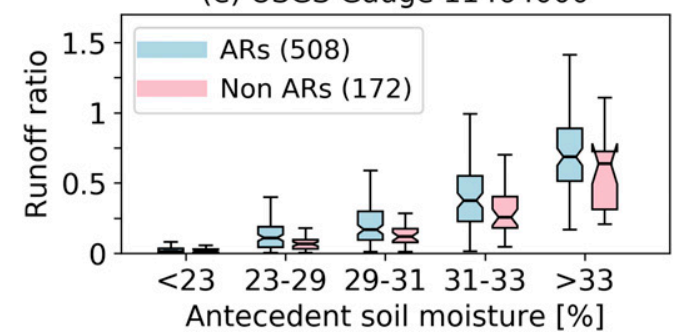

(b) USGS Gauge 11461000

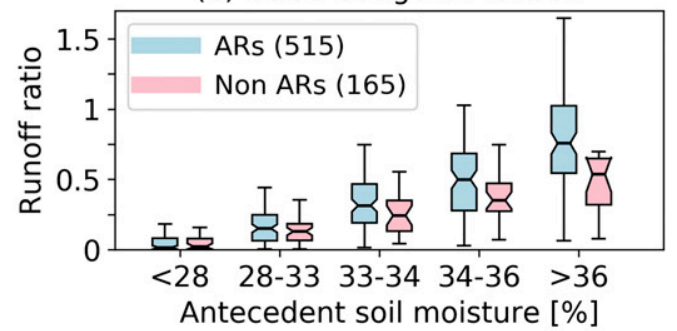

(d) USGS Gauge 11463000

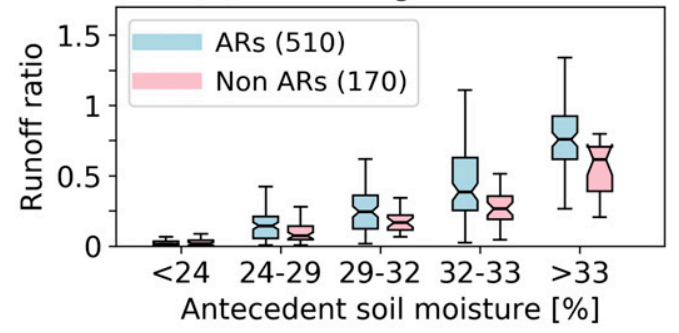

(f) USGS Gauge 11467000

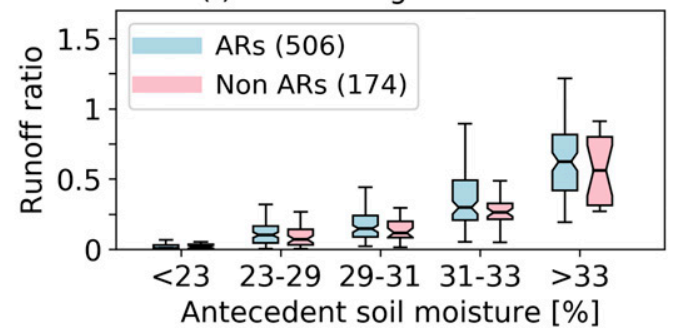

FIG. 7. Boxplots with an interval of 20th percentile of the simulation-based runoff ratio vs ASM of POT N10 extreme precipitation events (with threshold set to 10 events per year on average) during WY 1950-2017 at six USGS stream gauges. The POT events are categorized by ARs and non ARs, with number of events shown in legends.

We then examined the partial correlation between the $\mathrm{SP}_{2 \mathrm{~d}}$ and observed peak daily flow (denoted as PF) given

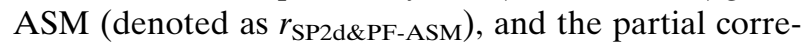
lation between ASM and observed PF given $\mathrm{SP}_{2 \mathrm{~d}}$ (denoted as $r_{\text {ASM\&PF-SP2d }}$ ) (see Fig. 9a). $\mathrm{SP}_{2 \mathrm{~d}}$ had higher correlations with observed $\mathrm{PF}$, ranging from 0.69 to 0.80 across six gauges in $\mathrm{POT}_{\mathrm{N} 3}$ events, than ASM with observed $\mathrm{PF}$, ranging from 0.40 to 0.67 across six gauges in $\mathrm{POT}_{\mathrm{N} 3}$ events, but all correlations are statistically significant with $p \leq 0.01 ; r_{\mathrm{ASM} \& \mathrm{PF}-S \mathrm{SP} 2 \mathrm{~d}}$ generally increased with drainage areas. Both correlations were higher when using the simulated PF since the ASM was from the model (see Fig. 9b). The effects of POT threshold on $r_{\text {SP2d\&PF-ASM }}$ and $r_{\text {ASM\&PF-SP2d }}$ varied by gauge location.

\section{d. Warming effect}

\section{1) TRENDS IN HISTORICAL POT EXTREME EVENTS}

We examined the trend in POT extreme precipitation events (based on gridded daily precipitation averaged over drainage area) and POT extreme discharge events (based on observed daily streamflow with reservoir effects removed) at six stream gauges throughout the basin with thresholds $\mathrm{POT}_{\mathrm{N} 1}, \mathrm{POT}_{\mathrm{N} 2}$, and $\mathrm{POT}_{\mathrm{N} 3}$ during WY 1950-2017 (see Table S2). Trends in POT extreme discharge events are not necessarily in agreement with trends in POT extreme precipitation events since whether the extreme precipitation events lead to extreme discharge events depends strongly on ASM (and more weakly on storm total precipitation).

No significant trends were found in extreme precipitation. However, weak (but statistically significant) downward trends were found at some gauges for extreme discharge, particularly in $\mathrm{POT}_{\mathrm{N} 2}$ extreme discharge events (see Fig. 10a), which are consistent with weak (but statistically significant) downward trends in the $\mathrm{SP}_{2 \mathrm{~d}}$ of extreme discharge events at most gauges (see Fig. 10c). However, statistically significant downward trends in the $\mathrm{SP}_{2 \mathrm{~d}}$ do not necessarily lead to significant decreases in PF despite their high correlation due to the influence of ASM, which is most obvious at downstream gauges. One hypothesis for the stronger trends in $\mathrm{SP}_{2 \mathrm{~d}}$ 

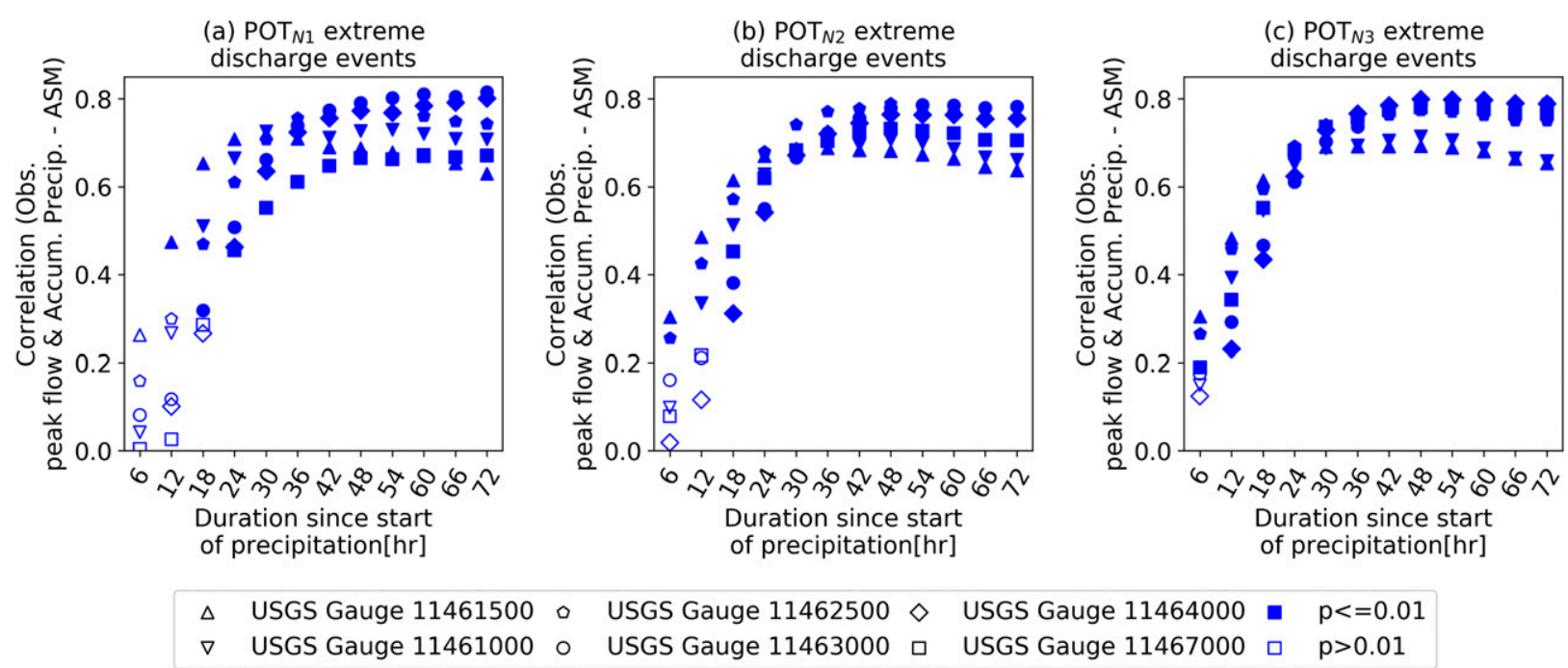

FIG. 8. Relationship between accumulated precipitation and observed peak daily flow given ASM in (a) POT $_{\mathrm{N} 1}$ extreme discharge events (with threshold set to one event per year on average), (b) $\mathrm{POT}_{\mathrm{N} 2}$ extreme discharge events (two events per year on average), and (c) $\mathrm{POT}_{\mathrm{N} 3}$ extreme discharge events (three events per year on average) during WY 1950-2017 at six USGS stream gauges.

as contrasted with PF shown in Fig. 10 is that the absence of trends in ASM (see Fig. 10b) is (somewhat) modulating the trends in precipitation. The absence of trends in ASM could be related to 1) cancellation of increased evaporative demand due to warmer temperature by slight increases in small precipitation amounts, which would need additional analysis, or 2) timing of the events, which is pretty critical for fall versus winter. This is a topic that could be investigated in detail in future work.

Both extreme discharge and its corresponding $\mathrm{SP}_{2 \mathrm{~d}}$ generally decreased at all gauges in $\mathrm{POT}_{\mathrm{N} 1}, \mathrm{POT}_{\mathrm{N} 2}$, and $\mathrm{POT}_{\mathrm{N} 3}$. In contrast, ASM only decreased at 2, 3, and 4 gauges in $\mathrm{POT}_{\mathrm{N} 1}, \mathrm{POT}_{\mathrm{N} 2}$, and $\mathrm{POT}_{\mathrm{N} 3}$, but none of the trends in ASM were significant except the one $(p<0.1)$ at gauge 11462500 in $\mathrm{POT}_{\mathrm{N} 3}$ events (see Table S2).

\section{2) TeMPERATURE EFFECT}

To assess the effect of increased temperature alone, we compared the trends in extreme discharge under temperature scenarios T1950 and T2017 (see Table S2). The relative change in trends of extreme discharge was very small: from $-2.4 \%-5.7 \%$ across six gauges in $\mathrm{POT}_{\mathrm{N} 2}$ extreme discharge events (in all cases, extreme discharge was on average smaller for T2017 than T1950 especially at downstream gauges, presumably because of increased evapotranspiration and hence decreased ASM). We also examined the correlation between ASM and observed $\mathrm{PF}$ in extreme discharge events given $\mathrm{SP}_{2 \mathrm{~d}}$ under $\mathrm{T} 1950$ and T2017 in late fall (October-December) and winter (January-March) months (see Fig. 11). ASM had a larger impact on extreme discharge in winter than in late fall months at the upstream gauges, and the reverse was true at downstream gauges. Warming slightly increased the effect of ASM on extreme discharge in the late fall months but had little effect in the winter months, possibly due to that there usually are enough minor storms in winter and ASM is fairly wet.

\section{Discussion}

We note that there are some limitations of our study based on the available data. One is the low spatial resolution of the NCEP-NCAR reanalysis dataset that the AR date catalog is based on. Other limitations are the representation of reservoir impacts on streamflow, and systematic modeling error (especially at upstream gauges). We used the AR catalog based on the NCEPNCAR dataset because of its long record. Despite of its coarse spatial resolution, others have found that AR detection algorithms based on the NCEP-NCAR reanalysis identify (mostly) the same storms as other reanalysis datasets with finer spatial resolution (but shorter records) - for example, ERA-Interim and MERRA2particularly the stronger and longer ones (Ralph et al. 2019b). We used a reservoir module, DHSVM-res, to remove the reservoir impacts on streamflow at downstream gauges to estimate naturalized flows (see Table 1 and Figs. S3-S5 for model performance). Finally, to mitigate the potential impacts of the systematic modeling error, we used observations in the analysis where they were available as much as possible such as the long-term trend analysis of the peak flow in section $4 \mathrm{~d}$.

As mentioned above, we selected both POT extreme precipitation events and extreme discharge events based 
(a) Observed peak daily flow vs.

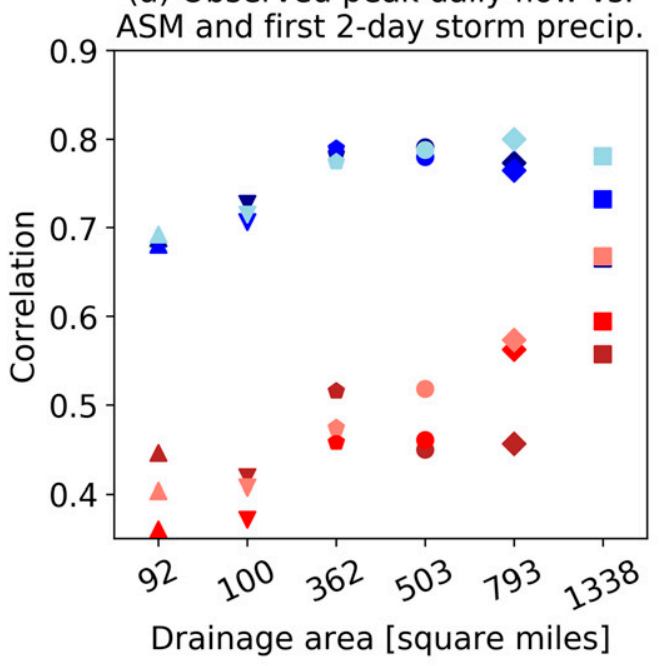

(b) Simulated peak daily flow vs.

ASM and first 2-day storm precip.

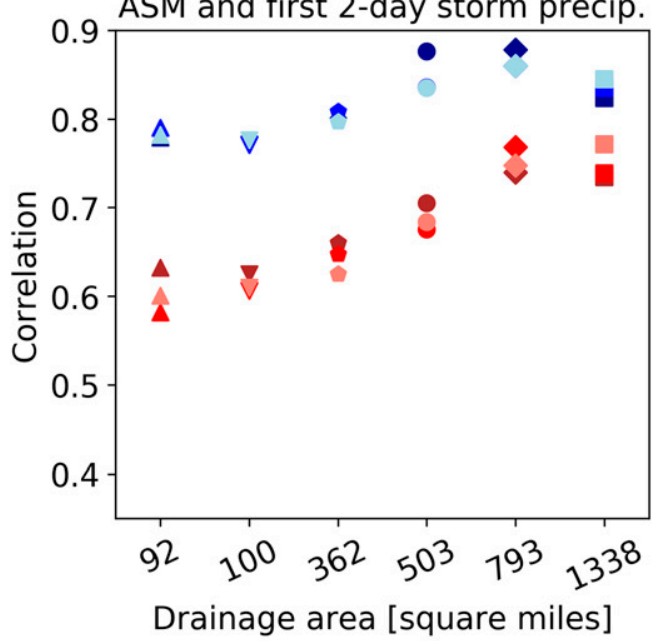
- $r_{S P 2 d \& P F-A S M}$ in POT ${ }_{N 1}$ extreme discharge events
- $r_{S P 2 d \& P F-A S M}$ in POT $_{N 2}$ extreme discharge events
$r_{S P 2 d \& P F-A S M}$ in POT $_{N 3}$ extreme discharge events
- $r_{A S M \& P F-S P 2 d}$ in POT ${ }_{N 1}$ extreme discharge events
- $r_{A S M \& P F-S P 2 d}$ in $\mathrm{POT}_{N 2}$ extreme discharge events
- $r_{A S M \& P F-S P 2 d}$ in POT $_{N 3}$ extreme discharge events

$\begin{array}{ll}\Delta & \text { USGS Gauge } 11461500 \\ \nabla & \text { USGS Gauge } 11461000 \\ \diamond & \text { USGS Gauge } 11462500 \\ \diamond & \text { USGS Gauge } 11463000 \\ \diamond & \text { USGS Gauge } 11464000 \\ \square & \text { USGS Gauge } 11467000\end{array}$

FIG. 9. (a) Correlation between first 2-day accumulated storm precipitation and observed peak daily flow given ASM (denoted as $r_{\text {SP2d\&PF-ASM }}$ ), and correlation between ASM and observed peak daily flow given first 2-day accumulated storm precipitation (denoted as $r_{\mathrm{ASM} \& \mathrm{PF}-\mathrm{SP} 2 \mathrm{~d}}$ ) in $\mathrm{POT}_{\mathrm{N} 1}, \mathrm{POT}_{\mathrm{N} 2}$, and $\mathrm{POT}_{\mathrm{N} 3}$ extreme discharge events (i.e., one, two, and three events per year on average) during WY 1950-2017 at six USGS stream gauges.

(b) As in (a), but with simulated peak daily flow. All correlations are statistically significant with $p \leq 0.01$.

on daily observations, as in many previous studies (e.g., Lang et al. 1999; Begueria et al. 2011; Mallakpour and Villarini 2017). However, runoff ratios as well as peak daily discharges are more strongly related to storm total precipitation than peak daily precipitation. In other words, POT extreme precipitation events may not necessarily lead to POT extreme discharge events of the same category. Figure 12 shows corresponding categories of peak observed daily flow led by $\mathrm{POT}_{\mathrm{N} 1}, \mathrm{POT}_{\mathrm{N} 2}$, and $\mathrm{POT}_{\mathrm{N} 3}$ extreme precipitation events during $\mathrm{WY}$ 1950-2017 at downstream-most USGS gauge 11467000 (Russian River near Guerneville). In general, almost all extreme precipitation events led to extreme discharge events of the same category when upstream average ASM was wetter than $32 \%$, corresponding to the 60 th percentile of $\mathrm{ASM}$ conditions in all $\mathrm{POT}_{\mathrm{N} 3}$ extreme precipitation events during WY1950-2017. When ASM was very dry (lower than $25 \%$, corresponding to the 20th percentile), $\mathrm{POT}_{\mathrm{N} 1}, \mathrm{POT}_{\mathrm{N} 2}$, and $\mathrm{POT}_{\mathrm{N} 3}$ extreme precipitation events with storm total precipitation exceeding 209, 204, and $70 \mathrm{~mm}$, respectively, might still be able to lead to extreme discharge events of the same category.
For the same gauge, we further examined its runoff ratios and ASM for the largest historical extreme discharge events with crests exceeding flood stage (see Table 3). For these flood events, the runoff ratio ranged from 0.25 to 1.16 with a median value of 0.88 . The lowest value of 0.25 for the event on 10 March 1995 was due to a consecutive dependent small peak in the hourly streamflow data, leading to an early end of the streamflow event according to the predefined event separation criteria. Aside from this event (classification of which arguably is an artifact of the storm precipitation identification procedure), all of the historical major flood events had simulation-based runoff ratios greater than 0.67 and ASM greater than $33.6 \%$, the latter corresponding to the 77th percentile of ASM conditions in all $\mathrm{POT}_{\mathrm{N} 3}$ extreme precipitation events during WY 1950 2017. Ralph et al. (2019a) examined the relationship between the AR scale and major flooding at this gauge (see Table 5 in their paper). They found that 6 out of 10 AR events in the highest category (in terms of IVT intensity and AR duration) were associated with major flooding during 1980-2017. They hypothesized that the three that did not lead to major flooding (one occurred 


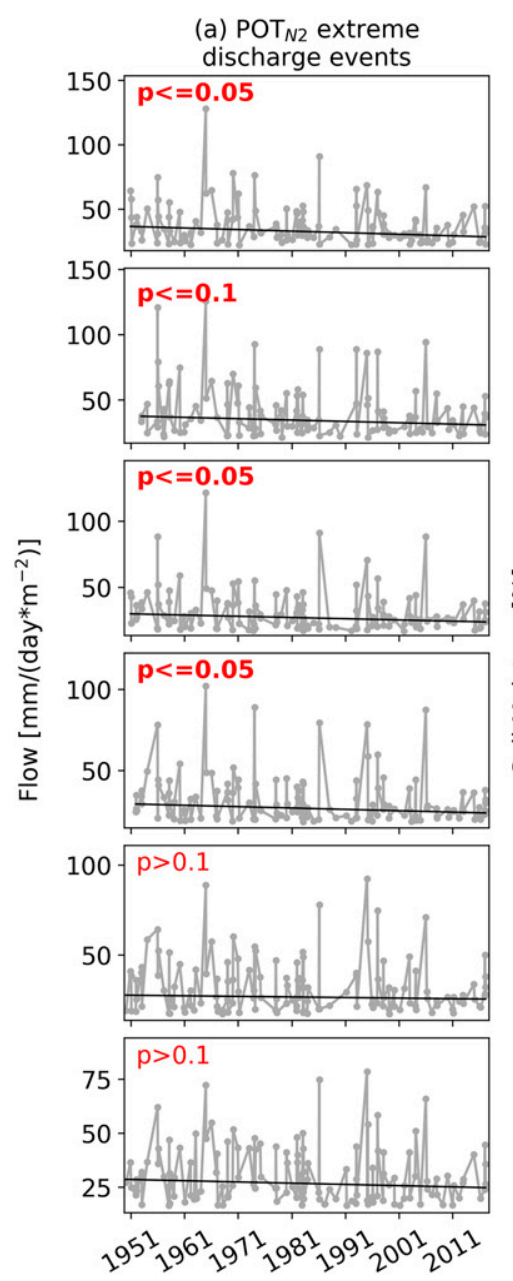

(b) Antedecent soil moisture
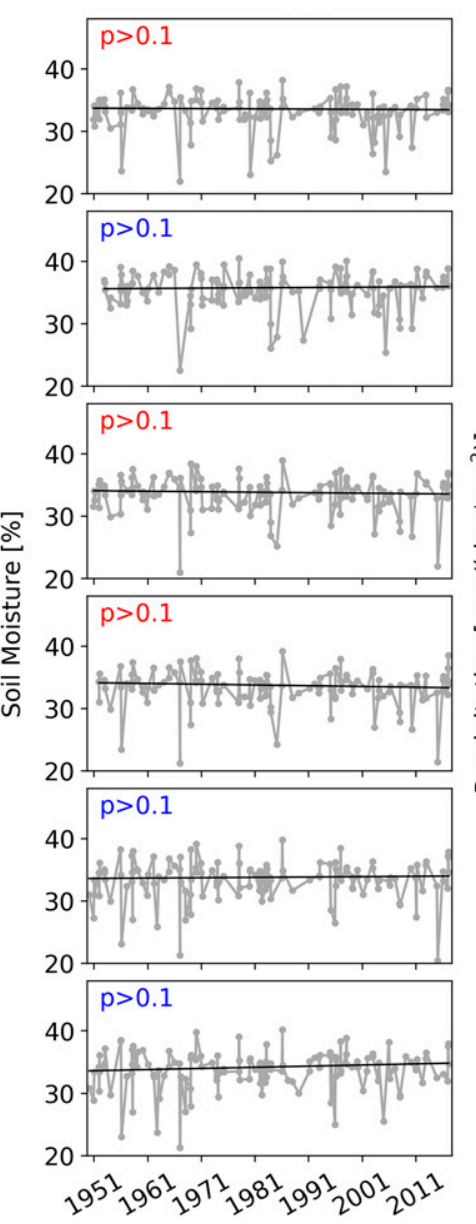

(c) First 2-day precipitation
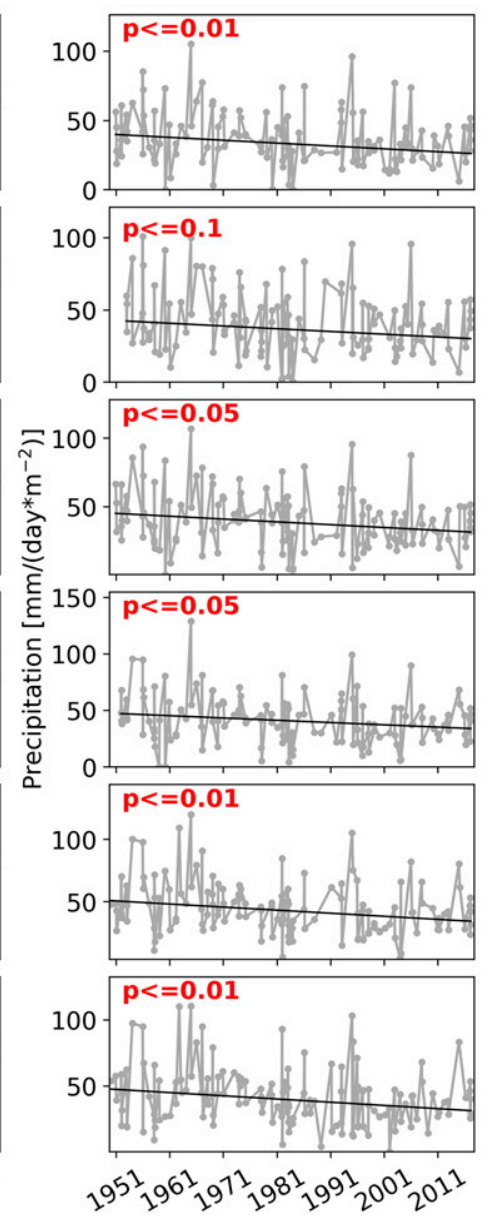

USGS Gauge

11462500

USGS Gauge 11464000

USGS Gauge

11461500

USGS Gauge

11461000

SGS Gauge 11463000

USGS Gauge 11467000

FIG. 10. Trends in (a) observed peak daily streamflow and (b) ASM from model hourly simulation, and (c) first 2-day accumulated storm precipitation of $\mathrm{POT}_{\mathrm{N} 2}$ extreme discharge events (threshold set to two events per year on average). The $p$ values are shown in plots, categorized by $p \leq 0.01,0.01<p \leq 0.05,0.05<p \leq 0.1, p \leq 0.1$, and $p>0.1$, with positive trends are marked in blue and negative in red. The $p$ values not greater than 0.1 are marked in bold font.

when streamflow data were not available) were related to dry soils. We showed here (see Table S3) that the ASM values were less than $20 \%$ (volumetric water content expressed as percent) for these three events, which corroborates their hypothesis. Furthermore, five out of the six AR events that led to flooding had ASM values greater than $32 \%$. The remaining one was the smallest flood event among the six, with an ASM of $22 \%$.

Long-term trends in temperature alone had little effect on the ASM in POT extreme discharge events, indicating that the changes in ASM were largely caused by antecedent precipitation. We examined the relative effects of temperature and antecedent precipitation on $\triangle \mathrm{ASM}$ by calculating the partial correlation between $\triangle \mathrm{ASM}$ and accumulated precipitation given accumulated evapotranspiration (ET; denoted as $r_{\triangle \mathrm{ASM}} \& \mathrm{P}-\mathrm{ET}$ ), and partial correlation between $\Delta$ ASM and ET given $P$ (denoted as $r_{\Delta \text { ASM\&ET-P) }}$ under different pre-event durations (from 2 days to 12 weeks) in late fall (October-December) and winter (January-March; see Figs. S6a,b). The accumulated $P$ had a larger effect on $\triangle \mathrm{ASM}$ than ET, and its relative effect decreased as pre-event duration lengthened. The influence of ET on $\triangle \mathrm{ASM}$ was larger in late fall than winter. We further examined the impact of warming on $\triangle \mathrm{ASM}$. Warming slightly increased the effect of ET on $\triangle \mathrm{ASM}$ in late fall especially when the pre-event duration exceeded one month. Warming barely affected the influence of ET on $\triangle \mathrm{ASM}$ in winter.

\section{Conclusions}

We first assessed the contribution of ARs to the extreme precipitation and extreme discharge events based on daily observations in California's Russian River basin 


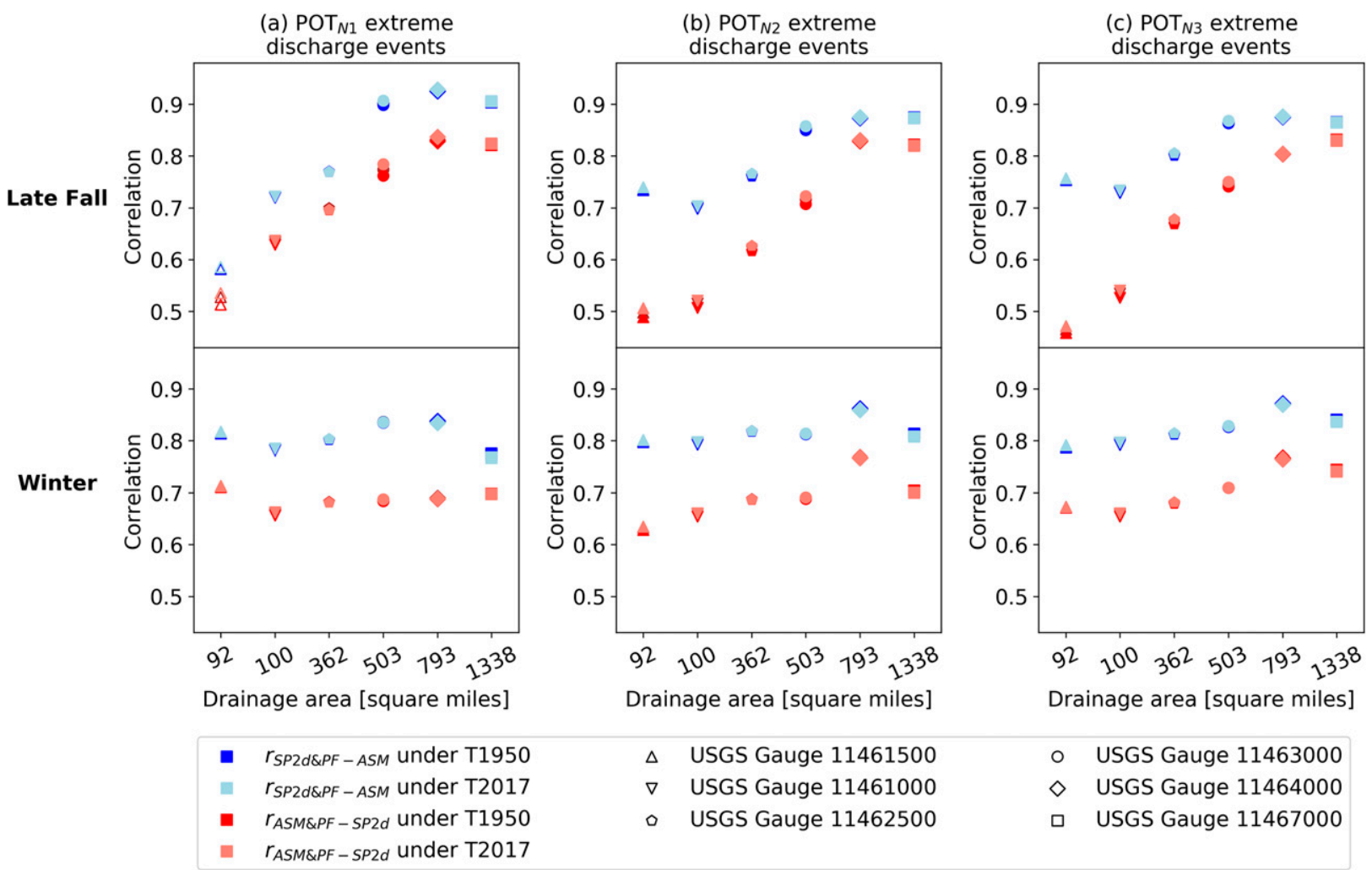

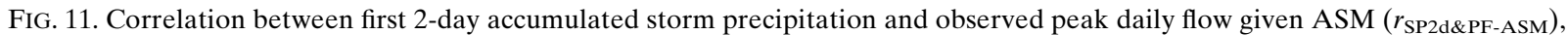
and correlation between ASM and observed peak daily flow given first 2-day accumulated storm precipitation ( $\left.r_{\mathrm{ASM} \& \mathrm{PF}-\mathrm{SP} 2 \mathrm{~d}}\right)$ in (a) $\mathrm{POT}_{\mathrm{N} 1}$, (b) $\mathrm{POT}_{\mathrm{N} 2}$, and (c) $\mathrm{POT}_{\mathrm{N} 3}$ extreme discharge events (i.e., one, two, and three events per year on average) during WY 1950-2017 at six USGS stream gauges. (top panel) Events in late fall (October-December) and (bottom panel) events in winter (January-March). All correlations are statistically significant with $p \leq 0.05$. The ones with $p \leq 0.01$ are shown by solid symbols.

using the POT method with varying thresholds (hence, number of events) during WY 1950-2017. We then examined the role of ASM on historical AR flooding to answer two questions: 1) Under what ASM conditions would extreme precipitation events lead to extreme discharge events of the same POT category? 2) For extreme discharge events, what is the role of ASM on peak flow? Recent studies suggest that observed changes in (a) $\mathrm{POT}_{N 1}$ extreme precip. events

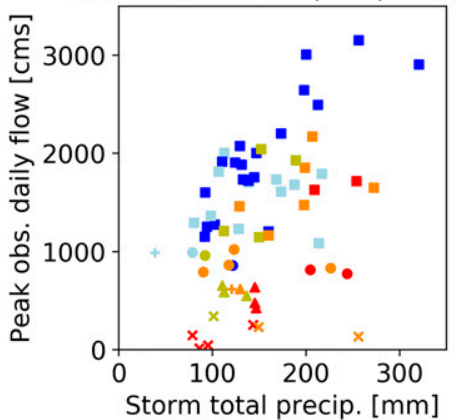

(b) $\mathrm{POT}_{N 2}$ extreme precip. events

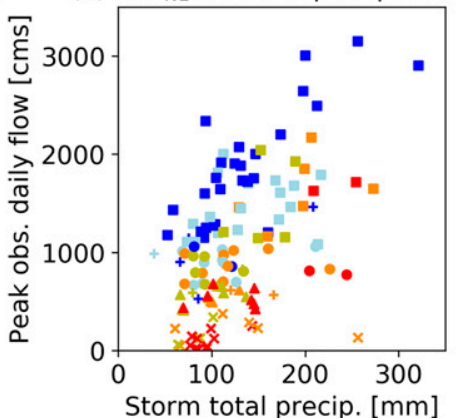

(c) $\mathrm{POT}_{N 3}$ extreme precip. events

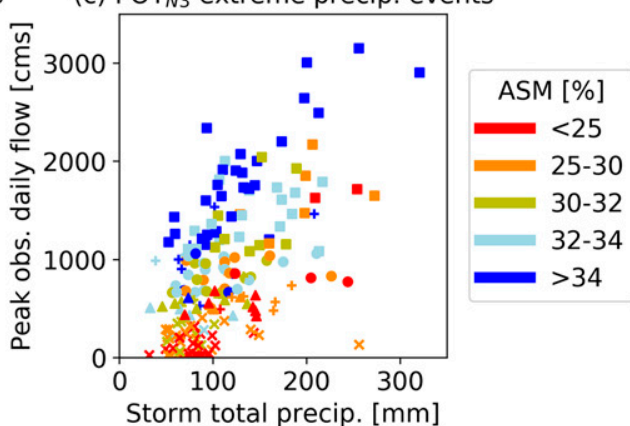

FIG. 12. Corresponding categories of peak observed daily flow led by (a) $\mathrm{POT}_{\mathrm{N} 1}$, (b) $\mathrm{POT}_{\mathrm{N} 2}$, and (c) $\mathrm{POT}_{\mathrm{N} 3}$ extreme precipitation events (i.e., one, two, and three events per year on average) during WY 1950-2017 at downstream-most USGS gauge 11467000 (Russian River near Guerneville). 
TABLE 3. Simulation-based runoff ratio and ASM of discharge events with crest exceeding major flood stage (40 ft) at the downstream-most USGS gauge 11467000 (Russian River near Guerneville) during WY 1950-2017. The NWS flood stage observations are measured at the USGS gauge 11467002 (Russian River at Guerneville), a few kilometers away from the USGS gauge 11467000 .

\begin{tabular}{|c|c|c|c|c|c|c|}
\hline $\begin{array}{l}\text { NWS event } \\
\text { rank }\end{array}$ & Date & $\begin{array}{l}\text { Observed crest } \\
\text { of flood } \\
\text { stage }(\mathrm{ft})\end{array}$ & $\begin{array}{l}\text { Simulated } \\
\text { hourly } \\
\text { peak }(\mathrm{cms})\end{array}$ & $\begin{array}{c}\text { Simulation-based } \\
\text { runoff ratio }\end{array}$ & $\begin{array}{c}\text { Simulated ASM } \\
\text { (volumetric water } \\
\text { content expressed as \%) }\end{array}$ & $\begin{array}{c}\text { Simulated ASM percentile } \\
\text { in historical } \text { POT }_{\mathrm{N} 3} \\
\text { precipitation events }(\%)\end{array}$ \\
\hline 1 & 18 Feb 1986 & 49.5 & 3545 & 1.15 & 40.2 & 100.0 \\
\hline 2 & 10 Jan 1995 & 48.0 & 4046 & 0.88 & 36.0 & 94.8 \\
\hline 3 & 23 Dec 1955 & 47.6 & 4004 & 1.02 & 38.4 & 98.4 \\
\hline 4 & 23 Dec 1964 & 47.4 & 4491 & 0.76 & 34.3 & 85.3 \\
\hline 5 & 1 Jan 1997 & 45.0 & 2326 & 1.16 & 38.3 & 97.9 \\
\hline 6 & 5 Jan 1966 & 42.5 & 3134 & 0.88 & 35.0 & 90.6 \\
\hline 7 & 1 Jan 2006 & 41.8 & 3169 & 0.67 & 34.0 & 80.6 \\
\hline 8 & 10 Mar 1995 & 41.5 & 1780 & 0.25 & 28.5 & 31.9 \\
\hline 9 & 24 Jan 1970 & 41.3 & 3067 & 1.09 & 39.7 & 99.5 \\
\hline 10 & 1 Feb 1963 & 41.1 & 1963 & 0.89 & 33.6 & 77.0 \\
\hline 11 & 17 Jan 1974 & 40.7 & 2555 & 0.83 & 36.0 & 95.3 \\
\hline 12 & 27 Jan 1983 & 40.4 & 2699 & 0.76 & 34.6 & 86.4 \\
\hline \multirow[t]{4}{*}{13} & 25 Feb 1958 & 40.2 & 2201 & 0.86 & 34.6 & 86.9 \\
\hline & Median & & 3067 & 0.88 & 35.0 & 90.6 \\
\hline & Max & & 4491 & 1.16 & 40.2 & 100.0 \\
\hline & Min & & 1780 & 0.25 & 28.5 & 31.9 \\
\hline
\end{tabular}

extreme precipitation associated with a general warming have not necessarily lead to corresponding changes in floods, and changes in ASM could be a primary missing link. We finally examined how the observed warming during the past 68 years had affected ASM and thus extreme discharge events. Based on our analysis, we find the following:

1) Most extreme precipitation and flood events in the Russian River basin are associated with ARs-up to $99 \%$ of extreme precipitation events and up to $95 \%$ of flood events, depending on the threshold used. The non-AR events were mostly of minor severity, with very few falling in the upper 25 th percentile of all extreme precipitation or discharge events.

2) The runoff ratio during extreme precipitation events is much more strongly related to ASM than to storm total precipitation. When ASM is wet (e.g., upstream average ASM greater than $32 \%$ at the downstreammost stream gauge 11467000, Russian River near Guerneville) or storm precipitation is sufficiently large, almost all extreme precipitation events lead to extreme discharge events of the same POT category. Among the extreme discharge events, however, the first 2-day storm precipitation had a greater effect on the peak flow than did ASM, but the effects of ASM on peak flow increases as drainage area increases.

3) We found no trends in the magnitude of extreme precipitation but weak downward trends in the magnitude of extreme discharge at some stream gauges in the Russian River basin during the period WY 1950-2017. We found no trends in ASM for extreme discharge events despite the fact that ASM was significantly correlated with peak flow; rather downward trends in extreme discharge are caused mostly by changes in the first 2-day storm precipitation. The ASM for extreme discharge events (which occur mostly in late fall and winter) were affected more by antecedent precipitation than evapotranspiration and hence temperature increases had weak effects on ASM.

Acknowledgments. We thank Huilin Gao and Gang Zhao from Texas A\&M University for providing the DHSVM-res codes and time series of reservoir surface areas extracted from Landsat data. The research supported herein was funded by the Center for Western Weather and Water Extremes (CW3E) at the Scripps Institution of Oceanography via AR Program Phase I, 4600010378 TO\#15 Am 22, sponsored by the California Department of Water Resources.

\section{REFERENCES}

Barth, N. A., G. Villarini, M. A. Nayak, and K. White, 2017: Mixed populations and annual flood frequency estimates in the western United States: The role of atmospheric rivers. Water Resour. Res., 53, 257-269, https://doi.org/10.1002/ 2016WR019064.

Begueria, S., M. Angulo-Martinez, S. M. Vicente-Serrano, J. I. Lopez-Moreno, and A. El-Kenawy, 2011: Assessing trends in extreme precipitation events intensity and magnitude using non-stationary peaks-over-threshold analysis: A case study in northeast Spain from 1930 to 2006. Int. J. Climatol., 31, 2102-2114, https://doi.org/10.1002/joc.2218. 
Berghuijs, W. R., R. A. Woods, C. J. Hutton, and M. Sivapalan, 2016: Dominant flood generating mechanisms across the United States. Geophys. Res. Lett., 43, 4382-4390, https:// doi.org/10.1002/2016GL068070.

Blume, T., E. Zehe, and A. Bronstert, 2007: Rainfall-runoff response, event-based runoff coefficients and hydrograph separation. $\mathrm{Hy}$ drol. Sci. J., 52, 843-862, https://doi.org/10.1623/hysj.52.5.843.

Bohn, T. J., B. Livneh, J. W. Oyler, S. W. Running, B. Nijssen, and D. P. Lettenmaier, 2013: Global evaluation of MTCLIM and related algorithms for forcing of ecological and hydrological models. Agric. For. Meteor., 176, 38-49, https://doi.org/ 10.1016/j.agrformet.2013.03.003.

Cao, Q., N. Sun, J. Yearsley, B. Nijssen, and D. P. Lettenmaier, 2016: Climate and land cover effects on the temperature of Puget Sound streams. Hydrol. Processes, 30, 2286-2304, https://doi.org/10.1002/hyp.10784.

—, T. H. Painter, W. R. Currier, J. D. Lundquist, and D. P. Lettenmaier, 2018: Estimation of precipitation over the OLYMPEX domain during winter 2015/16. J. Hydrometeor., 19, 143-160, https://doi.org/10.1175/JHM-D-17-0076.1.

Castillo, V. M., A. Gomez-Plaza, and M. Martinez-Mena, 2003: The role of antecedent soil water content in the runoff response of semiarid catchments: A simulation approach. J. Hydrol., 284, 114-130, https://doi.org/10.1016/S0022-1694(03)00264-6.

Cordeira, J. M., F. M. Ralph, A. Martin, N. Gaggini, J. R. Spackman, P. J. Neiman, J. J. Rutz, and R. Pierce, 2017: Forecasting atmospheric rivers during CalWater 2015. Bull. Amer. Meteor. Soc., 98, 449-459, https://doi.org/10.1175/BAMS-D-15-00245.1.

Crow, W. T., F. Chen, R. H. Reichle, and Q. Liu, 2017: L band microwave remote sensing and land data assimilation improve the representation of prestorm soil moisture conditions for hydrologic forecasting. Geophys. Res. Lett., 44, 5495-5503, https://doi.org/10.1002/2017GL073642.

Daly, C., R. Neilson, and D. Phillips, 1994: A statistical topographic model for mapping climatological precipitation over mountainous terrain. J. Appl. Meteor., 33, 140-158, https://doi.org/ 10.1175/1520-0450(1994)033<0140:ASTMFM>2.0.CO;2.

, M. Halbleib, J. I. Smith, W. P. Gibson, M. K. Doggett, G. H. Taylor, J. Curtis, and P. P. Pasteris, 2008: Physiographically sensitive mapping of climatological temperature and precipitation across the conterminous United States. Int. J. Climatol. 28, 2031-2064, https://doi.org/10.1002/joc.1688.

DeFlorio, M. J., D. E. Waliser, B. Guan, D. A. Lavers, F. M. Ralph, and F. Vitart, 2018: Global assessment of atmospheric river prediction skill. J. Hydrometeor., 19, 409-426, https://doi.org/ 10.1175/JHM-D-17-0135.1.

Dettinger, M., F. Ralph, T. Das, P. Neiman, and D. Cayan, 2011: Atmospheric rivers, floods and the water resources of California Water, 3, 445-478, https://doi.org/10.3390/w3020445.

Entekhabi, D., and Coauthors, 2010: The Soil Moisture Active Passive (SMAP) mission. Proc. IEEE, 98, 704-716, https:// doi.org/10.1109/JPROC.2010.2043918.

Gershunov, A., T. Shulgina, F. M. Ralph, D. A. Lavers, and J. J. Rutz, 2017: Assessing the climate-scale variability of atmospheric rivers affecting western North America. Geophys. Res. Lett., 44, 7900-7908, https://doi.org/10.1002/ 2017GL074175.

Guan, B., and D. E. Waliser, 2015: Detection of atmospheric rivers: Evaluation and application of an algorithm for global studies. J. Geophys. Res. Atmos., 120, 12 514-12 535, https://doi.org/ 10.1002/2015JD024257.

- N. P. Molotch, D. E. Waliser, E. J. Fetzer, and P. J. Neiman, 2010: Extreme snowfall events linked to atmospheric rivers and surface air temperature via satellite measurements. Geophys. Res. Lett., 37, L20401, https://doi.org/10.1029/2010GL044696.

Gupta, H. V., H. Kling, K. K. Yilmaz, and G. F. Martinez, 2009: Decomposition of the mean squared error and NSE performance criteria: Implications for improving hydrological modeling. J. Hydrol., 377, 80-91, https://doi.org/10.1016/j.jhydrol.2009.08.003.

Hamlet, A. F., and D. P. Lettenmaier, 2007: Effects of 20th century warming and climate variability on flood risk in the western U.S. Water Resour. Res., 43, W06427, https://doi.org/10.1029/ 2006WR005099.

Hecht, C. W., and J. M. Cordeira, 2017: Characterizing the influence of atmospheric river orientation and intensity on precipitation distributions over North Coastal California. Geophys. Res. Lett., 44, 9048-9058, https://doi.org/10.1002/2017GL074179.

Hughes, M., K. M. Mahoney, P. J. Neiman, B. J. Moore, M. Alexander, and F. M. Ralph, 2014: The landfall and inland penetration of a flood-producing atmospheric river in Arizona. Part II: Sensitivity of modeled precipitation to terrain height and atmospheric river orientation. J. Hydrometeor., 15, 1954-1974, https://doi.org/10.1175/JHM-D-13-0176.1.

Kalnay, E., and Coauthors, 1996: The NCEP/NCAR 40-Year Reanalysis Project. Bull. Amer. Meteor. Soc., 77, 437-471, https:// doi.org/10.1175/1520-0477(1996)077<0437:TNYRP>2.0.CO;2.

Kerr, Y. H., and Coauthors, 2010: The SMOS mission: New tool for monitoring key elements of the global water cycle. Proc. IEEE, 98, 666-687, https://doi.org/10.1109/JPROC.2010.2043032.

Lamjiri, M. A., M. D. Dettinger, F. M. Ralph, and B. Guan, 2017: Hourly storm characteristics along the US West Coast: Role of atmospheric rivers in extreme precipitation. Geophys. Res. Lett., 44, 7020-7028, https://doi.org/10.1002/2017GL074193.

Lang, M., T. Ouarda, and B. Bobee, 1999: Towards operational guidelines for over-threshold modeling. J. Hydrol., 225, 103-117, https://doi.org/10.1016/S0022-1694(99)00167-5.

Lavers, D. A., and G. Villarini, 2015: The contribution of atmospheric rivers to precipitation in Europe and the United States. J. Hydrol., 522, 382-390, https://doi.org/10.1016/j.jhydrol.2014.12.010.

, D. E. Waliser, F. M. Ralph, and M. D. Dettinger, 2016: Predictability of horizontal water vapor transport relative to precipitation: Enhancing situational awareness for forecasting western US extreme precipitation and flooding. Geophys. Res. Lett., 43, 2275-2282, https://doi.org/10.1002/2016GL067765.

Leung, L. R., and Y. Qian, 2009: Atmospheric rivers induced heavy precipitation and flooding in the western US simulated by the WRF regional climate model. Geophys. Res. Lett., 36, L03820, https://doi.org/10.1029/2008GL036445.

Mallakpour, I., and G. Villarini, 2017: Analysis of changes in the magnitude, frequency, and seasonality of heavy precipitation over the contiguous USA. Theor. Appl. Climatol., 130, 345-363, https://doi.org/10.1007/s00704-016-1881-z.

Martin, A., and Coauthors, 2018: Evaluation of atmospheric river predictions by the WRF model using aircraft and regional mesonet observations of orographic precipitation and Its forcing. J. Hydrometeor., 19, 1097-1113, https://doi.org/ 10.1175/JHM-D-17-0098.1.

Maurer, E. P., A. W. Wood, J. C. Adam, D. P. Lettenmaier, and B. Nijssen, 2002: A long-term hydrologically based dataset of land surface fluxes and states for the conterminous United States. J. Climate, 15, 3237-3251, https://doi.org/10.1175/ 1520-0442(2002)015<3237:ALTHBD>2.0.CO;2.

Mondal, A., and P. P. Mujumdar, 2015: Modeling non-stationarity in intensity, duration and frequency of extreme rainfall over India. J. Hydrol., 521, 217-231, https://doi.org/10.1016/ j.jhydrol.2014.11.071 
Nayak, M. A., and G. Villarini, 2018: Remote sensing-based characterization of rainfall during atmospheric rivers over the central United States. J. Hydrol., 556, 1038-1049, https:// doi.org/10.1016/j.jhydrol.2016.09.039.

_, _ and D. A. Lavers, 2014: On the skill of numerical weather prediction models to forecast atmospheric rivers over the central United States. Geophys. Res. Lett., 41, 4354-4362, https://doi.org/10.1002/2014GL060299.

Neiman, P. J., F. M. Ralph, A. B. White, D. E. Kingsmill, and P. O. G. Persson, 2002: The statistical relationship between upslope flow and rainfall in California's coastal mountains: Observations during CALJET. Mon. Wea. Rev., 130, 1468-1492, https://doi.org/ 10.1175/1520-0493(2002)130<1468:TSRBUF $>2.0 . C O ; 2$.

_ L. L. Schick, F. M. Ralph, M. Hughes, and G. A. Wick, 2011: Flooding in western Washington: The connection to atmospheric rivers. J. Hydrometeor., 12, 1337-1358, https://doi.org/ 10.1175/2011JHM1358.1.

—_, F. M. Ralph, B. J. Moore, M. Hughes, K. M. Mahoney, J. M. Cordeira, and M. D. Dettinger, 2013: The landfall and inland penetration of a flood-producing atmospheric river in Arizona. Part I: Observed synoptic-scale, orographic, and hydrometeorological characteristics. J. Hydrometeor., 14, 460-484, https://doi.org/10.1175/JHM-D-12-0101.1.

,,,--- and R. J. Zamora, 2014: The regional influence of an intense sierra barrier jet and landfalling atmospheric river on orographic precipitation in northern California: A case study. J. Hydrometeor., 15, 1419-1439, https://doi.org/10.1175/ JHM-D-13-0183.1.

Nikolopoulos, E. I., E. N. Anagnostou, M. Borga, E. R. Vivoni, and A. Papadopoulos, 2011: Sensitivity of a mountain basin flash flood to initial wetness condition and rainfall variability. J. Hydrol., 402, 165-178, https://doi.org/10.1016/j.jhydrol.2010.12.020.

Paltan, H., D. Waliser, W. H. Lim, B. Guan, D. Yamazaki, R. Pant, and S. Dadson, 2017: Global floods and water availability driven by atmospheric rivers. Geophys. Res. Lett., 44, 10387-10395, https://doi.org/10.1002/2017GL074882.

Penna, D., H. J. Tromp-van Meerveld, A. Gobbi, M. Borga, and G. Dalla Fontana, 2011: The influence of soil moisture on threshold runoff generation processes in an alpine headwater catchment. Hydrol. Earth Syst. Sci., 15, 689-702, https:// doi.org/10.5194/hess-15-689-2011.

Radatz, T. F., A. M. Thompson, and F. W. Madison, 2013: Soil moisture and rainfall intensity thresholds for runoff generation in southwestern Wisconsin agricultural watersheds. Hydrol. Processes, 27, 3521-3534, https://doi.org/10.1002/hyp.9460.

Ralph, F. M., P. J. Neiman, D. E. Kingsmill, P. O. Persson, A. B. White, E. T. Strem, E. D. Andrews, and R. C. Antweiler, 2003: The impact of a prominent rain shadow on flooding in California's Santa Cruz Mountains: A CALJET case study and sensitivity to the ENSO cycle. J. Hydrometeor., 4, 1243-1264, https://doi.org/ 10.1175/1525-7541(2003)004<1243:TIOAPR >2.0.CO;2.

,-- , G. Wick, S. Gutman, M. Dettinger, D. Cayan, and A. White, 2006: Flooding on California's Russian River: Role of atmospheric rivers. Geophys. Res. Lett., 33, L13801, https:// doi.org/10.1029/2006GL026689.

_ linking research and forecasting operations. Bull. Amer. Meteor. Soc., 94, 1187-1211, https://doi.org/10.1175/BAMS-D-12-00080.1. , T. Coleman, P. Neiman, R. Zamora, and M. Dettinger, 2013b: Observed impacts of duration and seasonality of atmospheric-river landfalls on soil moisture and runoff in coastal Northern California. J. Hydrometeor., 14, 443-459, https://doi.org/10.1175/JHM-D-12-076.1.
_ M. D. Dettinger, M. M. Cairns, T. J. Galarneau, and J. Eylander, 2018: Defining "atmospheric river": How the Glossary of Meteorology helped resolve a debate. Bull. Amer. Meteor. Soc., 99, 837-839, https://doi.org/10.1175/BAMS-D-17-0157.1.

_ J. J. Rutz, J. M. Cordeira, M. Dettinger, M. Anderson, D. Reynolds, L. J. Schick, and C. Smallcomb, 2019a: A scale to characterize the strength and impacts of atmospheric rivers. Bull. Amer. Meteor. Soc., 100, 269-289, https://doi.org/ 10.1175/BAMS-D-18-0023.1.

— , and Coauthors, 2019b: ARTMIP-early start comparison of atmospheric river detection tools: how many atmospheric rivers hit northern California's Russian River watershed? Climate Dyn., 52, 4973-4994, https://doi.org/10.1007/s00382-018-4427-5.

Rutz, J. J., W. J. Steenburgh, and F. M. Ralph, 2014: Climatological characteristics of atmospheric rivers and their inland penetration over the western United States. Mon. Wea. Rev., 142, 905-921, https://doi.org/10.1175/MWR-D-13-00168.1.

Schaake, J., A. Henkel, and S. Cong, 2004: Application of PRISM climatologies for hydrologic modeling and forecasting in the western U.S. 18th Conf. on Hydrology, Seattle, WA, Amer. Meteor. Soc., 5.3, https://ams.confex.com/ams/ 84Annual/techprogram/paper_72159.htm.

Sharma, A., C. Wasko, and D. P. Lettenmaier, 2018: If precipitation extremes are increasing, why aren't floods? Water Resour. Res., 54, 8545-8551, https://doi.org/10.1029/2018WR023749.

Shepard, D. S., 1984: Spatial statistics and models. Computer Mapping: The SYMAP Interpolation Algorithm, G. L. Gaile and C. J. Willmott, Eds., D. Reidel, 133-145.

Shields, C. A., and Coauthors, 2018: ARTMIP: Project goals and experimental design. Geosci. Model Dev., 11, 2455-2474, https://doi.org/10.5194/gmd-11-2455-2018.

Thomas, N. W., A. A. Amado, K. E. Schilling, and L. J. Weber, 2016: Evaluating the efficacy of distributed detention structures to reduce downstream flooding under variable rainfall, antecedent soil, and structural storage conditions. Adv. Water Resour., 96, 74-87, https://doi.org/10.1016/j.advwatres.2016.07.002.

USWRC, 1982: Guidelines for determining flood flow frequency. Bulletin 17B of the Hydrology Subcommittee, 183 pp., https:// water.usgs.gov/osw/bulletin17b/dl_flow.pdf.

Waliser, D., and B. Guan, 2017: Extreme winds and precipitation during landfall of atmospheric rivers. Nat. Geosci., 10, 179-U183, https://doi.org/10.1038/ngeo2894.

Wasko, C., and A. Sharma, 2017: Global assessment of flood and storm extremes with increased temperatures. Sci. Rep., 7, 7945, https://doi.org/10.1038/s41598-017-08481-1.

Wigmosta, M. S., L. W. Vail, and D. P. Lettenmaier, 1994: A distributed hydrology-vegetation model for complex terrain. Water Resour. Res., 30, 1665-1679, https://doi.org/10.1029/94WR00436.

Woldemeskel, F., and A. Sharma, 2016: Should flood regimes change in a warming climate? The role of antecedent moisture conditions. Geophys. Res. Lett., 43, 7556-7563, https://doi.org/ 10.1002/2016GL069448.

Wood, A. W., and D. P. Lettenmaier, 2006: A test bed for new seasonal hydrologic forecasting approaches in the western United States. Bull. Amer. Meteor. Soc., 87, 1699-1712, https:// doi.org/10.1175/BAMS-87-12-1699.

Zhao, G., H. L. Gao, B. S. Naz, S. C. Kao, and N. Voisin, 2016: Integrating a reservoir regulation scheme into a spatially distributed hydrological model. Adv. Water Resour., 98, 16-31, https://doi.org/10.1016/j.advwatres.2016.10.014.

Zhu, Y., and R. Newell, 1998: A proposed algorithm for moisture fluxes from atmospheric rivers. Mon. Wea. Rev., 126, 725-735, https:// doi.org/10.1175/1520-0493(1998)126<0725:APAFMF>2.0.CO;2. 